\title{
The Bone-Vasculature Axis: Calcium Supplementation and the Role of Vitamin K
}

\author{
Grzegorz B. Wasilewski ${ }^{1,2}$, Marc G. Vervloet ${ }^{3}$ and Leon J. Schurgers ${ }^{1 *}$ \\ 1 Department of Biochemistry, Cardiovascular Research Institute Maastricht, Maastricht University, Maastricht, Netherlands, \\ ${ }^{2}$ Nattopharma ASA, Hovik, Norway, ${ }^{3}$ Department of Nephrology and Amsterdam Cardiovascular Sciences, Amsterdam \\ University Medical Centers, Amsterdam, Netherlands
}

Calcium supplements are broadly prescribed to treat osteoporosis either as monotherapy or together with vitamin $D$ to enhance calcium absorption. It is still unclear whether calcium supplementation significantly contributes to the reduction of bone fragility and

\section{OPEN ACCESS}

Edited by:

Dwight A. Towler,

University of Texas Southwestern Medical Center, United States

Reviewed by:

Yabing Chen,

University of Alabama at Birmingham,

United States

Joshua D. Hutcheson,

Florida International University,

United States

Sasha Anna Singh,

Harvard Medical School,

United States

Alexander N. Kapustin,

AstraZeneca, United Kingdom

*Correspondence:

Leon J. Schurgers

l.schurgers@maastrichtuniversity.nI

Specialty section:

This article was submitted to

Atherosclerosis and Vascular

Medicine,

a section of the journal

Frontiers in Cardiovascular Medicine

Received: 21 September 2018

Accepted: 14 January 2019

Published: 05 February 2019

Citation:

Wasilewski GB, Vervloet MG and

Schurgers LJ (2019) The

Bone-Vasculature Axis: Calcium

Supplementation and the Role of

Vitamin $K$.

Front. Cardiovasc. Med. 6:6.

doi: 10.3389/fcrm.2019.00006 fracture risk. Data suggest that supplementing post-menopausal women with high doses of calcium has a detrimental impact on cardiovascular morbidity and mortality. Chronic kidney disease (CKD) patients are prone to vascular calcification in part due to impaired phosphate excretion. Calcium-based phosphate binders further increase risk of vascular calcification progression. In both bone and vascular tissue, vitamin K-dependent processes play an important role in calcium homeostasis and it is tempting to speculate that vitamin $\mathrm{K}$ supplementation might protect from the potentially untoward effects of calcium supplementation. This review provides an update on current literature on calcium supplementation among post-menopausal women and CKD patients and discusses underlying molecular mechanisms of vascular calcification. We propose therapeutic strategies with vitamin K2 treatment to prevent or hold progression of vascular calcification as a consequence of excessive calcium intake.

Keywords: calcium paradox, vitamin K, vascular calcification, calcium supplements, bone loss

\section{INTRODUCTION}

Calcium is an abundant element in nature and is a major component of sedimentary rock that covers 75 to $80 \%$ of the Earth's surface. Calcium is also widely abundant in the human body, primarily in bone, and teeth. Calcium salts are occasionally found outside bone in a variety of tissues; this is broadly termed as extra-skeletal calcification. In these extra-skeletal sites, calcium exists in multiple forms, including amorphous calcium phosphate, hydroxyapatite, and magnesium whitlockite. A remarkable observation is that under several pathological conditions, as will be discussed, calcium mineral content of bone declines, while it is increasing on these extra-osseous sites. This has been termed the "calcium paradox" and was introduced to describe the paradoxical correlation between lower bone calcium content with parallel increased vascular calcium content (1). The calcium paradox refers to epidemiological data reporting that postmenopausal women experience bone loss, yet simultaneously screen positive for vascular calcification. This phenomenon is common in osteoporotic women and patients suffering from chronic kidney disease (CKD). Prevalence and morbidity of both cardiovascular disease and osteoporosis are increasing in the global population. Such observations have been noted in several studies, where a correlation of low bone mineral density (BMD) was associated with increased cardiovascular mortality (2-6). 
The use of calcium supplements has been widely advised due to their assumed ability to support bone health and BMD $(7,8)$. Calcium is an essential element for bone growth during childhood (9), as well as in preserving bone mineral density during adolescence (10). However, a systematic review and meta-analysis of the effects of calcium supplementation along with vitamin $\mathrm{D}$ treatment showed that this treatment was not associated with a lower incidence of fracture risk in adults, questioning whether calcium supplementation contributes to the maintenance of healthy bone (11). In turn, recent data suggest that calcium supplements increase prevalence of myocardial infarction (12), and may increase risk of coronary artery calcification (CAC) (13). Moreover, higher doses of calcium from supplements than calcium obtained from dietary intake might promote cardiovascular calcification (14). Thus, despite the relative benefit of calcium supplementation for bone, calcium supplements became controversial because of a possibly increased cardiovascular risk. Substantially different from calcium from dietary sources, calcium form supplements induce an acute rise in serum calcium levels that highly oscillates in blood for up to $6 \mathrm{~h}(15,16)$. The plasma calcium concentration is tightly regulated by vitamin $\mathrm{D}$, parathyroid hormone (PTH), and calcitonin $(17,18)$.

Vitamin K-dependent proteins (VKDP) also play an important role regulating mineralization both in bone and the vasculature. Osteocalcin (OC) is produced exclusively by osteoblasts and supports the binding of calcium to the bone mineral matrix, whereas matrix Gla-protein (MGP) is synthesized by vascular smooth muscle cells and chondrocytes to prevent ectopic calcification. While hepatically produced coagulation factors are the prototypical VKDP, the extra-hepatic VKDP also unequivocally need vitamin $\mathrm{K}$ as cofactor to become biologically active. Related to that, vitamin $\mathrm{K} 2$ has been shown to prevent bone loss and strength and prevents stiffening of arteries $(19,20)$. Western diet does not provide sufficient vitamin $\mathrm{K}$ to activate all OC and MGP that is produced $(21,22)$. Also in CKD patients, vitamin $\mathrm{K}$ deficiency is prevalent, so $\mathrm{K} 2$ supplementation has been suggested as treatment option to attenuate vascular calcification $(23,24)$.

In this review we provide the latest insights of the calcium paradox and the potential of using vitamin $\mathrm{K}$ to support both bone and vascular health.

\section{BONE METABOLISM}

Calcification generally is a physiological process, necessary to build bone and dentin. Bone provides structural support, strength, necessary for locomotion, and protection from the environment. The balance in bone formation and bone resorption is crucial for optimal bone health. A disturbed balance of this process results in bone loss and is termed osteoporosis. During childhood bone is formed and bone peak mass is achieved during young adulthood, after which bone mass gradually declines. Bone loss is the consequence of bone resorption outbalancing bone formation (25). This is accompanied by bone architectural changes including trabecular bone becoming thinner, less abundant, and osteoclastic perforation of cortical bone (26).

\section{Bone Formation}

The skeleton is systematically renewed in the process of bone remodeling to maintain strength and rigidity. Bone remodeling can be considered to be part of calcium homeostasis system and enables the skeleton to adapt to changes. Bones adapt their structure depending on their function, mechanical strain and need for stability during development. It is mediated on the surface of cortical and trabecular bone, and at anatomically different sites named basic multicellular subunits (27).

Two pathways of bone formation exist, together termed osteogenesis. The first is known as endochondral ossification and involves a differentiation of mesenchymal cells into chondrocytes or osteoblasts $(28,29)$. As chondrocytes mature, they expand in size and become hypertrophic and eventually undergo apoptosis, secreting vesicles that initiate mineralization of extracellular matrix (30). As they die, with vascular evasion and matrix remodeling (osteoclast mediated), the calcified cartilage is subsequently replaced by bone. Nestin-positive mesenchymal progenitors associated with the invading vasculature differentiate into bone-forming osteoblasts and deposit a type I collagenbased bone matrix on the degraded cartilage template (31), (32). The second process of bone formation is intramembranous ossification. First, mesenchymal cells directly differentiate into osteoblasts, which are bone-forming cells. Next, type I collagen matrix is deposited by these cells, that can bind calcium salts, which form hydroxyapatite crystals. This mineralization of the matrix underlies the strength and compactness of the bone. With time, osteoblasts eventually become trapped in calcified extracellular matrix and transdifferentiate into osteocytes. Osteoblasts are the only bone cell type releasing the vitamin K-dependent protein OC (discussed below). As the newly formed bone is laid, its deposition must be tightly regulated to maintain homeostasis. This balance is achieved by boneresorbing cells, entering the blood vessels of bone, which are termed osteoclasts and are of macrophage origin. Each osteoclast is able to secrete hydrogen ions, thereby acidifying the bone surface dissolving mineralized matrix, followed by interactions that enhance the action of osteoblasts (33-35). Upon resorption, bone-matrix embedded osteocalcin is released contributing to its circulating levels (36).

\section{Bone Loss}

Bone loss is most typical in women after reaching the age of 50 years following menopause. The pattern of sex hormonal secretion drastically changes after the menopause, resulting in disbalance in bone turnover markers, making postmenopausal women susceptible to osteoporosis and fractures. Remarkably cardiovascular diseases are also more prevalent in postmenopausal women. Therefore, it is important to understand the molecular mechanisms by which hormonal changes leads to both osteoporosis and cardiovascular disease $(37,38)$. The post-menopausal period is accompanied by substantial reduction of estrogen levels leading to bone resorption, yet simultaneously reducing calcium absorption 
(39). It is not the aim of this review to elaborate on the effect of estrogen on the vasculature [reviewed elsewhere (39)]. Instead, we will focus on specific pathways involved in calcium metabolism.

PTH is released upon hypocalcemia, indirectly stimulating release of calcium from bone. In $\mathrm{CKD}$, autonomous production of PTH may occur. Additionally, PTH promotes reabsorption of ultra-filtered calcium in distal tubules and activates vitamin D thereby increasing circulating calcium levels by raising gastrointestinal uptake of calcium $(17,18)$. Calcium-sensing receptors $(\mathrm{CaR})$ present on the surface of parathyroid glands enable sensing of circulating calcium concentration (40), contributing to calcium modulation.

Vitamin D is a fat-soluble vitamin that can be obtained from diet, sun exposure, or supplements, and is metabolized by a series of enzymatic reactions in the body producing its active 1,25-dihydroxyvitamin D form $(41,42)$. Vitamin D (in inactive form) is often prescribed in combination with calcium supplements. Active 1,25-dihydroxyvitamin D enhances absorption of intestinal calcium and phosphate thus contributing to the regulating of mineral balance $(43,44)$. In the absence of vitamin D, only $10-15 \%$ of intestinal calcium is absorbed, which can be increased to $30-40 \%$ in the presence of active vitamin D $(45,46)$. Vitamin D was found to stimulate production of vitamin K-dependent proteins, like osteocalcin (47). Osteocalcin is a protein involved in bone mineralization [reviewed elsewhere (48)]. Remarkably, inclusion of vitamin K in calcium and vitamin $\mathrm{D}$ supplements improved BMD and ucOC when compared with vitamin D and calcium alone (49).

CKD patients often experience deficiency of 1,25dihydroxyvitamin $\mathrm{D}$ as a consequence of lost kidney mass and the effects of fibroblast growth factor 23 (50), resulting in declined activity of 1-alpha hydroxylase (51-53). Reduced serum levels of 1,25-dihydroxyvitamin D lead to hypocalcemia on top of positive phosphate balance, both stimulating PTH release and eventually leading to secondary hyperparathyroidism.

\section{VASCULAR CALCIFICATION}

Vascular calcification is a pathological process, and has been firmly established as a risk factor for cardiovascular events and mortality $(54,55)$. Vascular calcification is a process of extraosseous mineral deposition in blood vessels, including large arteries such as aorta, carotid arteries, iliac arteries, and cardiac valves. Bone mineralization and vascular calcification share many similarities, including expression of bone-related proteins in the vasculature and secretion of extracellular vesicles (EVs) both preceding the phase of calcification $(56,57)$. Vascular calcification can occur either in the tunica media or tunica intima of the vessel wall. Medial calcification is also known as Möckenberg's sclerosis and involves vascular smooth muscle cell (SMC) calcification in the absence of previous local lipid accumulation, and inflammation. Medial calcification is related to $\mathrm{CKD}$, diabetes mellitus, and aging, and results in increased arterial stiffness and risk of cardiovascular events $(58,59)$. In contrast, intimal calcification is associated with atherosclerotic plaque formation and the amount of calcification is considered to be a measure of atherosclerotic burden (1).

For many years vascular calcification was considered as a clinically irrelevant process reliant of passive deposition of calcium crystals, merely reflecting a passive feature of disease and aging. Recent evidence however suggests otherwise, and vascular calcification appears to be a highly regulated process. SMCs release calcification inhibitors, thus efficiently preventing spontaneous calcification in spite of supersaturation of extracellular calcium and phosphate levels (60).

\section{Vascular Smooth Muscle Cell Phenotypic Switching}

SMCs are the main cellular component of the tunica media in arterial vessels providing structural support and regulating vascular tone and elasticity to alterations in pressure conditions. In physiology SMCs possess a contractile phenotype and express contractile-specific markers, including alpha-smooth muscle actin, calponin, and SM22alpha, enabling them to perform contraction of the vessel wall [reviewed elsewhere $(61,62)]$. SMC function is associated with a high level of phenotypic plasticity in order to perform a variety of functions including production of extracellular matrix and repair (61, 63). Several factors have been implicated in regulating SMC phenotype, including mineral imbalance (calcium, magnesium, and phosphate-induced loss of calcification inhibitors and presence of calcification promotors) (64). Downregulation of contractile markers is a hallmark for SMC phenotypic switching (65). It has been shown that phosphate can induce an osteochondrogenic phenotypic switching of SMC, as will be outlined in more detail below (61, 66-69), whereas elevated calcium levels shift the contractile phenotype toward a synthetic SMC phenotype (57). Both calcium- and phosphate- induced phenotypic switching are associated with an increase in the secretion of calcifying extracellular vesicles $(56,57)$.

\section{Elevated Phosphate Levels Promote Osteochondrogenic Differentiation of SMCs}

CKD patients often develop medial calcification (70). In CKD, a strong correlation between serum phosphate levels and vascular calcification is present $(71,72)$. In an animal model of CKD, arterial calcification developed after feeding animals a phosphorous-rich diet only (73). Initiation and progression of calcification in CKD patients correlates with impaired mineral metabolism represented by elevated serum level of phosphate and/or calcium (74). Moreover, high circulating phosphate levels have been linked to increased cardiovascular morbidity even among young people receiving dialysis (75) and in CKD patients (76). In vitro, elevated phosphate levels result in upregulation of bone-like markers in SMC including osterix, alkaline phosphatase (ALP), and Runx2, and downregulation of SMC contractility markers (77). SMC cultured 
in osteogenic cell culture media differentiate into calcifyingSMC resembling osteoblasts (68). In aortic valves of patients with aortic stenosis, valvular interstitial cells demonstrate similarities with osteoblasts (78), which also exhibit lamellar bone formation (79). Upon injury or in atherosclerosis, SMCs induce the release of platelet-derived growth factor (PDGF) similarly to platelets $(80,81)$. SMC are known to express the PDGF receptor subtypes and the level of expression is greatly increased in connective tissue and in SMCs followed by PDGF stimulation (82).

\section{THE CALCIUM PARADOX}

The paradoxical co-existence of declined calcium-mineral content in bone, and parallel increased arterial calcification, as a consequence of impaired calcium metabolism, is termed the calcium paradox. This is most pronounced in post-menopausal women and CKD patients. Many studies have consistently shown a coexistence of osteoporosis in post-menopausal women and increased calcification of either abdominal aorta and carotid arteries $(5,83-90)$. Such paradox of decreased bone mineral density and vascular calcification has also been documented in a population study of middle-aged men, suggesting it is not unique to women (91), and pointing to a specific metabolic abnormality. In patients with CKD disturbed calcium and phosphate homeostasis is present and many studies consistently reported bone abnormalities including decreased BMD and fractures and coexistence of increased vascular calcification and all-cause mortality (92-108).

Kidney Disease: Improving Global Outcomes (KDIGO) guidelines recommend the term chronic kidney disease-mineral bone disorder (CKD-MBD) to express this clinical syndrome encompassing mineral (e.g., calcium), bone, and cardiovascular calcification abnormalities that develop as a complication of CKD (109). In addition to bone disease, patients with CKD are also prone to vascular calcification, bone fragility and fractures. It has been shown that patients on dialysis, which is the end stage of CKD (CKD stage 5D), have an increased risk of fractures $(110,111)$ and vascular calcification $(112)$, and therefore the calcium paradox also exists in CKD patients. CKD pathological characteristics include biochemical imbalances leading to elevated levels of circulating phosphate (113-115). In untreated patients, circulating calcium levels are decreased due to vitamin D deficiency, whereas vitamin D supplementation might be beneficial in improving biochemical endpoints in CKD patients (116). Vitamin D is often used in combination with calcium supplementation therapy. In patients on dialysis, coronary artery calcification is prominent and contributes to high mortality and morbidity. However, this use of both calcium and vitamin $\mathrm{D}$, while being possibly protective for bone disease, may aggravate vascular calcification. Uraemia-related cardiovascular risk factors, including hyperphosphatemia and elevated $\mathrm{Ca} \times \mathrm{P}$ product, correlate with quicker onset of vascular calcification (117). Circumventing this calcium paradox may be accomplished by VKDP $(118,119)$, as will be outlined below.

\section{AGENTS THAT ALTER TISSUE MINERALIZATION}

In the following sections we will discuss treatments known to influence bone and vascular mineralization, and how they might impact calcium metabolism.

\section{Calcium Supplements}

Calcium is important for optimal bone health throughout life. Although dietary intake of calcium may suffice to meet the recommended daily intake, calcium supplements may be an option if diet falls short. dose Globally, recommendations for daily calcium intake vary. The Institute of Medicine (IOM) recommends a daily intake of $1,000 \mathrm{mg} /$ day for men aged 19 70 years and women $19-50$ years old, and 1,200 mg/day for older individuals (92) whereas National Osteoporosis Society suggests an intake between $800-1,000 \mathrm{mg}$ a day (120). While calcium intake comes from dietary sources such as dairy products, certain vegetables, and fortified foods, many people do not achieve the recommended intake from diet alone. It is estimated that $\sim 35 \%$ of the adult U.S. population uses calcium supplements (121). Calcium plays a vital role in various physiological activities, such as nerve conduction, muscle contraction, blood clotting, protein folding, brain function, and regulated cell death (apoptosis) (122, 123). Such broad function of calcium in the body requires precise regulation, and calcium oscillates between 2.15 and $2.60 \mathrm{mmol} / \mathrm{L}$ for total plasma calcium in adults and between 1.17 and 1.33 $\mathrm{mmol} / \mathrm{L}$ for plasma ionized calcium as free calcium represents some $45 \%$ of total circulating calcium levels. This free form is the regulated calcium and accounts for bone mineralization as well as pathological calcification (124)

\section{Calcium Forms, Absorption, and Effects}

Several formulations of calcium are available on the market, differing in bioavailability, and elemental calcium content. Calcium carbonate is the most common form available. However, many studies showed superiority of calcium citrate over calcium carbonate, due to higher bioavailability and because it does not require acidic stomach conditions before ingestion (102). In a study carried out in post-menopausal women supplemented with di-calcium phosphate over a period of 12 months, serum calcium levels did not vary significantly, and only urinary calcium increased progressively in time when compared to the control group. The increased excretion of calcium may indirectly reflect the rise of the renal threshold for excretion and together with the amount of absorbed calcium it may contribute to complications such as deposition in the vasculature (103).

One of the most applied therapeutic intervention for fracture risk is calcium in the form of pills or organic powder. Commercially available calcium is often marketed in combination with vitamin D3 to increase intestinal absorption of calcium (Table 1). It has been proposed that no more than $500 \mathrm{mg}$ of elemental calcium should be taken as single dose to maximize absorption and to avoid side effects, like gastrointestinal complaints (94). When calcium supplements are not exceeding the nutritional daily intake of $800 \mathrm{mg}$, a low cardiovascular risk was observed (104). Clinical guidelines consider a cumulative 
TABLE 1 | Comparison of calcium salts frequently used in calcium supplements.

\begin{tabular}{|c|c|c|c|}
\hline $\begin{array}{l}\text { Calcium } \\
\text { salt }\end{array}$ & $\begin{array}{l}\text { Elemental } \\
\text { calcium \% (w/v) }\end{array}$ & Bioavailability & Advantages/disadvantages \\
\hline Carbonate & 40 & High (comparable with citrate) & $\begin{array}{l}\text { Requires acidic stomach conditions before absorption, might } \\
\text { cause acidic rebound, cheap provides greatest amount of } \\
\text { elemental calcium }\end{array}$ \\
\hline $\begin{array}{l}\text { Tricalcium } \\
\text { phosphate }\end{array}$ & 38 & $\begin{array}{l}\text { Moderate (found lower absorption than citrate when used in } \\
\text { fortified juice) }\end{array}$ & High calcium content \\
\hline Citrate & 21 & High (higher than lactate/tricalcium phosphate) & Not dependent on stomach acidity, many tablets needed \\
\hline Gluconate & 9 & High (comparable with calcium carbonate) & Many tablets needed \\
\hline Lactate & 13 & High (comparable with calcium carbonate) & Many tablets needed \\
\hline Acetate & 25 & High (scarce information on human subjects) & Inexpensive, wide range of intestine $\mathrm{pH}$ absorption \\
\hline $\begin{array}{l}\text { Chloride } \\
\text { References }\end{array}$ & 27 & $\begin{array}{l}\text { High (intravenous injection for treatment of hypocalcemia) } \\
(93,94,125)\end{array}$ & $\begin{array}{l}\text { Not commonly prescribed low amount of elemental calcium } \\
(11,33-39,41)\end{array}$ \\
\hline
\end{tabular}

Salts are listed according to elemental calcium content which does not necessarily reflect on bioavailability. Absorption is also influenced by stomach acid due to the salt structure e.g., calcium carbonate is basic and needs hydrochloric acid in stomach to produce calcium chloride which is further absorbed.

calcium intake from foods and supplements that does not exceed 2,000 to 2,500 mg/d, as defined by National Academy of Medicine, as safe for cardiovascular disease outcome $(105,106)$.

Numerous studies and extensive meta-analyses reported on the efficacy and cost effectiveness of calcium supplementation (with or without vitamin D), in improving bone mineral density as well as decreasing fracture risk (83-85, 107, 108). Furthermore, in individuals with inadequate calcium intake, the supplementation plan seems to be beneficial in reducing fragility fractures especially in osteoporotic women $(86,107)$. Calcium supplementation was also demonstrated to be effective in preventing reduction in bone loss and turnover in healthy population (87). A recent double-blind controlled trial also proved the effectiveness of medium and high calcium intake in maximizing bone mineral density in adolescent girls (88). In addition, many studies described neutral or protective effects of calcium rich foods on cardiovascular outcomes including atherosclerosis, risk of infarction, stroke, and cardiovascular mortality $(89,90,126-130)$.

However, recent data challenge the assumption that calcium supplementation improves bone mineral density. A metaanalysis on the correlation between calcium supplementation alone or with vitamin $\mathrm{D}$ and bone mineral density in people over 50 years of age demonstrated little beneficial effect $(1-2 \%)$ in the first year with nearly no further benefits after 1 year on bone mineral density (8). With such low effects it would be challenging to implement calcium supplementation into standard treatment for reduction of fracture risk in the healthy elderly population (131). A recent review summarizing the use and efficacy of calcium supplementation in treating osteoporosis and fracture risk questions the use of calcium supplements because of the weak beneficiary effect on fracture risk while increasing the risk on gastrointestinal problems, kidney stones, and cardiovascular risk (132).

Despite positive outcomes of calcium supplementation, a risk for cardiovascular risk events may exist in specific population. It was recently shown that women who receive calcium supplementation were at higher risk for increased vascular morbidity and mortality, including myocardial infarction
(108, 133-139). In turn, recent systematic reviews and meta analyses do not confirm that supplementing calcium (with or without vitamin D) increased prevalence of coronary heart disease, cardiovascular mortality or all-cause mortality, data on which the above-mentioned statement by the National Academy of Medicine is based upon $(105,131)$. Rapidly elevated transient calcium levels in blood caused by excessive supplementary calcium have been suggested to promote coagulation when compared with placebo in postmenopausal women, likely due to interaction with platelets expressing calcium-sensing receptor (CaSR) $(140,141)$. Hypercoagulability is considered to have a reinforcing effect on atherosclerosis in animal studies, contributing to cardiovascular disease. Also many coagulation proteins have been described in human atherosclerotic plaques (142). These findings are in line with the association between high calcium intake and cardiovascular calcification in CKD patients (143). Reconciling these sometimes opposing details difficult. There appears to be some protection from fracture risks by calcium supplements, but its safety is still not sufficiently established. Therefore, additional research is still needed.

Calcium-based phosphate binders have been used extensively as a first-choice option since 1970 to alleviate hyperphosphatemia associated with CKD patients due to its low cost, availability, and effectiveness. These calcium-containing phosphate binders are given to CKD patients to complex dietary phosphate, thereby reducing phosphate uptake $(144,145)$.

As with most supplements, also calcium-containing phosphate binders have side effects, which include abdominal cramps, intestinal bloating, and diarrhea (146). Further, excessive intake of calcium supplements might also result in milk-alkali syndrome and hypercalcemia (92). In addition, also in patients with $\mathrm{CKD}$, the use of calcium-containing binders are associated with progression of $\mathrm{CKD}$, and the recently updated KDIGO guideline suggest to restrict its use (109).

\section{Vitamin K and Vitamin K-Dependent Proteins}

Vitamin K was discovered in 1929 by the Danish biochemist Henrik Dam during his experiments on cholesterol metabolism 
<smiles>CC1=C(C/C=C(\C)CCCC(C)CCCC(C)CCCC(C)C)C(=O)c2ccccc2C1=O</smiles><smiles>CC(C)=CCC/C(C)=C/CC/C(C)=C/CC/C(C)=C/CC1=C(C)C(=O)c2ccccc2C1=O</smiles>

Menaquinone-4 K2-MK-4
Phyloquinone (K1)<smiles>CC1=CC(=O)c2ccccc2C1=O</smiles>

Menadione ring

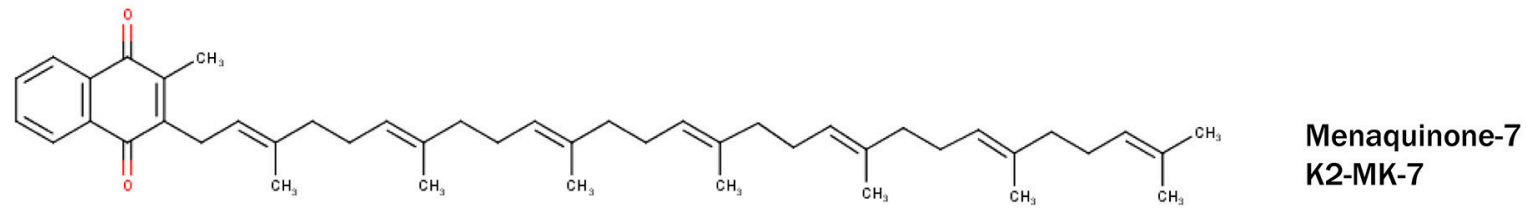

FIGURE 1 | Structural formulae of naturally occurring and biologically active Vitamin K-phylloquinone (K1) and menaquinones (K2-MK-4 and K2-MK-7). All vitamins share common menadione ring (also known as vitamin K3).

in chickens. When fed low-fat diets, chickens experienced prolonged clotting time and hemorrhage, which surprisingly could not be rescued when diet was enriched with cholesterol. Dam assumed a deficiency of a vitamin required for coagulation, which he termed "Koagulation vitamin," hence vitamin K (147). Indeed, vitamin $\mathrm{K}$ was shown to be a fat-soluble vitamin, consisting a group of structurally related compounds including vitamin K1 (phylloquinone) and vitamin K2 (menaquinones) (Figure 1). Vitamin K1 contains a phytyl chain, whereas K2 is classified according to the length of isoprenoids and indicated as MK- $n$, where $n$ represents the number of residues. Both vitamins share a common 2-methyl-1,4-naphthoquinone ring, also known as menadione. The main source of vitamin K1 is green vegetables (148), whereas vitamin K2 can be found in fermented foods such as soy beans, cheese, and sauerkraut. The richest source of vitamin $\mathrm{K} 2$ (MK-7) is a Japanese dish named Natto, which is produced from fermented soy beans with aid of the Bacillus Subtilis bacteria strain (149). In addition to nutritional consumption, gut bacteria Lactococcus (150) and Escherischia coli (151) are able to synthesize long chain menaquinones (Figure 1).

The primary biological function of both K-vitamins is being an unequivocal cofactor in the post-translational modification of VKDP via carboxylation of glutamic acid residues (Glu) to ycarboxylated-glutamic acid residues (152). To fulfill this function, vitamin $\mathrm{K}$ needs to be reduced to its active cofactor form (KH2) by quinone reductases. The enzyme y-glutamylcarboxylase (GGCX) oxidizes KH2 to vitamin K-epoxide (KO) (153).
Both vitamins $\mathrm{K} 1$ and $\mathrm{K} 2$ can partake in the activation of VKDP; however, long-chain menaquinones, which are more hydrophobic, have a higher bioavailability and longer half-life and thus bioactivity $(154,155)$.

VKDP are a group of proteins that require carboxylation of specific protein-bound glutamate-residues, allowing them to bind with high affinity to calcium. This was first demonstrated in coagulation, showing that VKDP of the coagulation cascade need carboxylation to acquire biological activity. This role of vitamin $\mathrm{K}$ on coagulation is clinically widely applied by the use of warfarin as anticoagulant treatment. The extra negative charge in VKDP bind via calcium to negatively charged phospholipids to exert their function. In the last three decades, extra-hepatic VKDP have been discovered, including OC, MGP, and Gla-rich protein (GRP; also termed Upper zone of growth plate and Cartilage Matrix Associated protein, Ucma) (156). The function of nonhepatic VKDP has recently be discovered and include prevention of vascular calcification (157) and importantly also promotion of bone metabolism (158). The current knowledge of vascular calcification inhibitors has gained attention of both scientists and clinicians to research their molecular action, aiming to alleviate disease caused by vascular calcification.

\section{Osteocalcin}

OC is a major non-collagenous protein abundantly present in bone, responsible for management of skeletal mineralization $(159,160)$. OC knock-out/null rodents undergo increased bone mineralization, followed by an increase in trabecular 


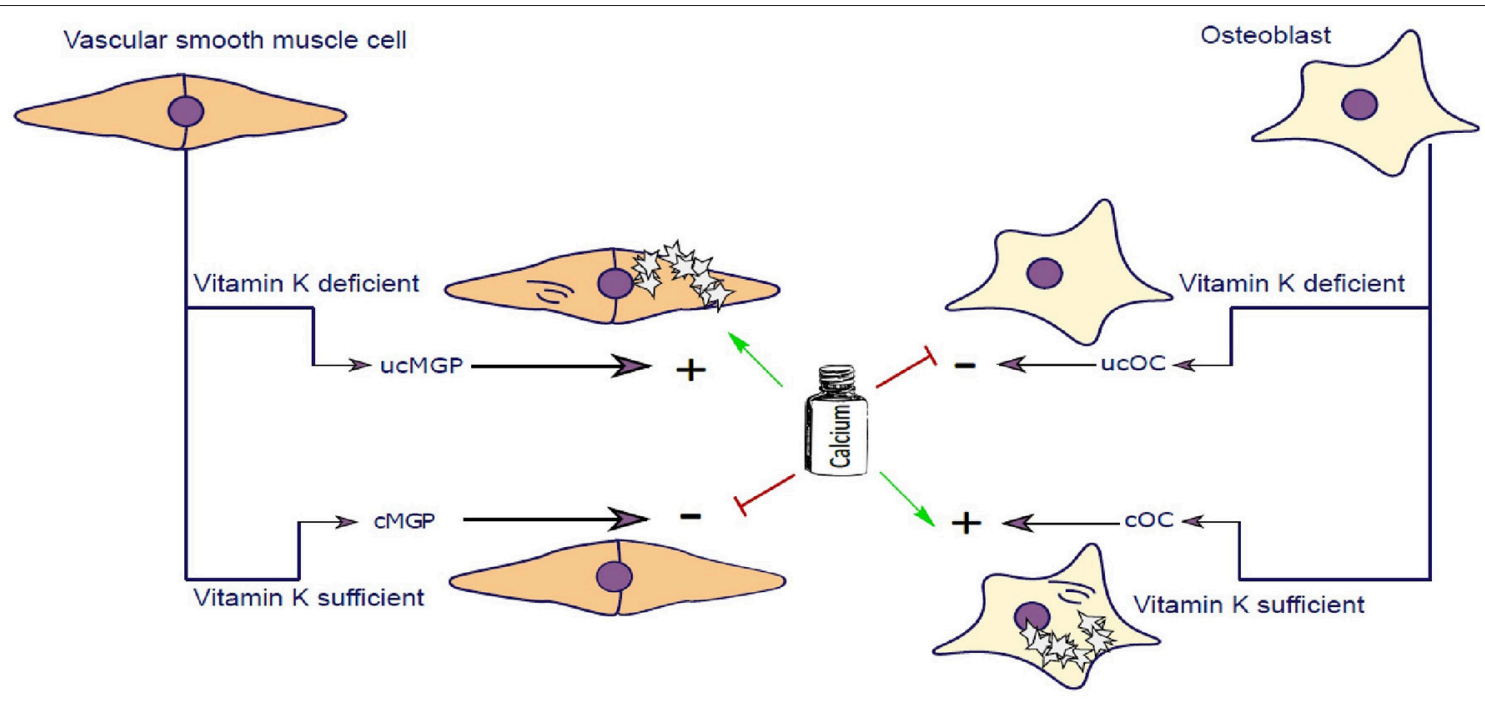

FIGURE 2 | Vascular smooth muscle cells (VSCMC) and osteoblasts are able to synthesize Matrix-Gla-Protein (MGP) and Osteocalcin (OC), respectively. In the presence of vitamin K both proteins are carboxylated (CMGP and $\mathrm{COC}$ ) preventing calcification of VSMC and promoting mineralization of Osteoblasts. Vitamin K-dependent carboxylation mechanism keeps extracellular matrix of VSMC free of calcification and simultaneously promotes mineralization of osteoblast matrix. In Chronic Kidney Disease patients, calcium serum levels are elevated further potentiating the calcification of SMCs. Similarly, in post-menopausal women, calcium homeostasis is further impaired contributing to impairment of calcium utilization by osteoblasts. In the event of vitamin K deficiency, both MGP and Osteocalcin are not carboxylated and cannot perform their molecular function.

thickness, density and bone volume (161-163). During skeletal development, bone mass increases due to the dominant function of osteoblasts which secrete OC, amongst other proteins, enabling bone to grow. In addition to bone function, OC is implicated in stimulating testosterone synthesis and insulin release $(164,165)$. Other roles of OC are not covered in this review and have been reviewed elsewhere (166). To execute its physiological function, OC needs to be activated by carboxylation, catalyzed by vitamin K. Carboxylated OC (cOC) has a high affinity for calcium ions and aids in forming a hydroxyapatite lattice preceding mineralization of bone (167, 168) (Figure 2). Upon bone degradation, OC, incorporated into mineralized bone, is liberated. Serum OC levels were negatively correlated with bone mineral density (BMD) in postmenopausal woman and healthy subjects (169-171). In a study of healthy girls, plasma phylloquinone was inversely correlated with circulating $\mathrm{OC}$ concentrations showing that a better vitamin $\mathrm{K}$ status was associated with decreased bone turnover in healthy girls (172).

\section{Matrix Gla Protein}

The discovery of MGP dates back to 1983 where it was first purified from bovine bone matrix and named after the presence of gamma-carboxyglutamate residues on MGP (173). Shortly thereafter MGP was confirmed to be present in cartilage, lung heart, kidney, and vasculature, with highest protein expression in SMCs and chondrocytes (174-176). Knocking out MGP in mice induced advanced medial calcification and subsequent vessel rupture followed by death in the majority of mice within 6 weeks after birth. This animal model resembles the human Keutel syndrome which is caused by a mutation in the MGP gene (177,
178), which impairs carboxylation of MGP thereby inducing intimal and medial calcification (179). MGP is also dependent on carboxylation of gla-residues, catalyzed by vitamin $\mathrm{K}$, to execute its function as an inhibitor of vascular calcification (Figure 2) (180, 181). Uncarboxylated MGP (ucMGP) is associated with increased risk of vascular calcification, and therefore some researchers advocate that vitamin $\mathrm{K}$ status in $\mathrm{CKD}$ patients should be carefully monitored (182).

Another mode of action of MGP, besides being an inhibitor of arterial calcification, is inhibition of bone morphogenic protein2/4 (BMP2/4) $(183,184)$. BMP2 was found to be present in human atherosclerotic lesions (185), acting as downstream signal for osteogenic phenotype switching of SMC by increasing the influx of phosphate into cells (186). In MGP-deficient SMCs, upregulation of osteogenic-specific proteins was notified (187) and it can be speculated that MGP prevents osteogenic transition of SMC by interacting with BMP-2 (188).

\section{Gla Rich Protein}

GRP, also known as Ucma, is a vitamin K-dependent protein secreted by chondrocytes $(189,190)$ and present in cartilage, bone (191), and vasculature $(192,193)$. Despite the creation of GRP knockout mice its precise molecular action remains to be elucidated, because these animals had no manifest deficits in cartilage or bone development (194). So far, the role of GRP has been implicated in calcium regulation in extracellular matrix (156, 192), and thus being an inhibitor of ectopic calcification (192, 193). Indeed, GRP inhibits calcification of aortic tissue by promoting a contractile SMC phenotype via increasing expression of $\alpha$-smooth muscle actin (193). Moreover, GRP was found to be directly associated with calcium-phosphate 
TABLE 2 | Occurrence of selected vitamin $\mathrm{K}$ dependent proteins in different tissue compartments.

\begin{tabular}{lccc}
\hline & Bone & Vasculature & Cartilage \\
\hline MGP & $\checkmark$ & $\checkmark$ & $\checkmark$ \\
$\begin{array}{l}\text { Gla rich protein } \\
\text { (UCMA) }\end{array}$ & $\checkmark$ & $\checkmark$ & $\checkmark$ \\
$\begin{array}{l}\text { Osteocalcin } \\
\text { Reference }\end{array}$ & $\checkmark$ & $?$ & $?$ \\
\hline
\end{tabular}

crystals suggesting that this protein-crystal interaction modulates calcification (156). Also, in CKD stage 5D, GRP inhibits $\mathrm{EV}$ and calcifying protein particles (CPP) induced vascular calcification (195). In addition, GRP was found to promote osteoblast (196) and chondrocyte differentiation $(189,190)$. More recently, it was shown that GRP inhibited phosphate-induced SMC calcification via BMP-dependent signaling suggesting its role in regulating osteochondrogenic differentiation of SMCs (69). As mentioned above, MGP also inhibits calcification via a BMP-dependent mechanisms $(57,197)$ and this novel function of GRP function via a BMP-dependent mechanism suggests that both MGP and GRP deficiency contribute to phosphate-induced vascular calcification and cardiovascular risk. Table 2 summarizes vitamin-K dependent proteins involved in calcification.

\section{Phosphate Binders and Vitamin K}

Despite many years of research there is no definite proof that phosphate binders improve outcome, despite their capacity to control phosphate. Although direct studies suggest superiority of non-calcium containing binders over calcium containing binders, it is still unclear if this is due to an advantage of non-calcium containing binders or added risks from calcium containing binders (143, 202-204) Even more striking is that the use of any phosphate binders in earlier CKD, despite lowering phosphate, did not reduce progression of coronary calcification (71). This conundrum may be explained by the recently demonstrated ability of phosphate binders to also bind vitamin $\mathrm{K}$ (Table 3 ). The advantage of lowering phosphate concentrations if thus offset by aggravation vitamin K deficiency. The lack of difference in this CKD patient subgroup could be explained by effective inherent protection in these patients or by simultaneous undesired binding of vitamin $\mathrm{K}$ by some phosphate binders resulting in vitamin $\mathrm{K}$ deficiency which serves as co-factor for enzymes that activate calcification inhibitors $(218,219)$ (Figure 3). More recently, it was shown that CKD patients on dialysis treated with the phosphate binder sevelamer revealed higher circulating levels of dpucMGP, the inactive form of MGP (221). These findings support the in vitro notion and hypothesis that phosphate binders induce a vitamin K-deficiency. Besides the above-mentioned phosphate binders, new forms have recently been developed such as iron-based phosphate binders. Iron oxyhydroxide have been proven to be as potent as sevelamer in decreasing phosphatemia (222), while apparently not interfering with vitamin K-metabolism (218).

\section{Vitamin K to Escape the Calcium Paradox}

As outlined, vitamin $\mathrm{K}$ has a role in healthy bone formation, while at the same time it provides protection against ectopic calcification, especially in the cardiovascular system. Therefore, it is tempting to speculate that the calcium paradox in fact reflects vitamin $\mathrm{K}$ deficiency.

It has been shown that patients with CKD frequently are vitamin K-deficient, which is likely attributable to dietary advice to limit their potassium intake (i.e., intake of green leafy vegetables and thus vitamin $\mathrm{K} 1$ ) and to lower phosphate intake (i.e., intake of dairy products and thus vitamin K2). Besides, these dietary restrictions, especially patients on dialysis frequently suffer loss of appetite, further affecting the intake of essential nutrients, including vitamin K. Another risk for vitamin $\mathrm{K}$ deficiency is the use of phosphate binders as outlined above. Finally, use of anticoagulant therapy with vitamin Kantagonists in CKD patients will propel this deficiency even further (223). Although novel direct oral anticoagulants are available, these are often considered unsuitable for patients with a glomerular filtration rate below $30 \mathrm{ml} / \mathrm{min} / 1.73 \mathrm{~m}^{2}$. Also, in healthy subjects it was shown that the majority has subclinical vitamin $\mathrm{K}$ deficiency as deduced from the presence of increased concentrations of uncarboxylated VKDP in the circulation (22, $180,224)$. Recent evidence, as outlined in detail above, suggests that vitamin $\mathrm{K}$ is an important factor in bone and vasculature in CKD patients and post-menopausal women, and that its role may be overlooked. It creates a window of opportunity to supplement vitamin $\mathrm{K}$ in the abovementioned subgroups including $\mathrm{CKD}$ patients and post/peri menopausal women frequently deficient in vitamin $\mathrm{K}$.

Although supplementation with vitamin K2 (MK-4) daily for 3 years did not improve bone mineral content or bone mineral density, it did maintain bone strength at femoral neck site in post-menopausal women (19), thus indicating a beneficial effect on post-menopausal bone strength loss. Aside from MK-4's known function for gamma carboxylation, and thereby preventing ectopic calcification to occur, it was shown to also promote maturation of osteoblasts (225) and to suppress osteoclast maturation while promoting their apoptosis $(226,227)$. MK-7, a long-chain menaquinone, was found to have more beneficial effect on bone and facilitates bone mineralization, including cortical bone structure as compared to MK-4 (228). In support to in vivo evidence, several trials assessed the feasibility of MK-7 as treatment for CKD and post-menopausal osteoporotic patients. It was shown that MK-7 (MenaQ7) improves bone strength at the femoral neck via increasing bone mineral content (BMC) and bone mineral density (BMD) (19, 229, 230). In addition, hemodialysis patients supplemented with MK-7 showed a substantial decrease in dp-ucMGP along with ucOC and PIVKA-II (protein induced by vitamin $\mathrm{K}$ absence or antagonism-II) in a dose-dependent manner, implicating that MK-7 improves vitamin K-status in liver, bone, and vasculature $(24,231)$. In osteoporotic patients, vitamin $\mathrm{K} 2$ resulted in elevated levels of $\mathrm{cOC}$ and prevented fractures when compared 
TABLE 3 | Summary of selected features and effects of available phosphate binders.

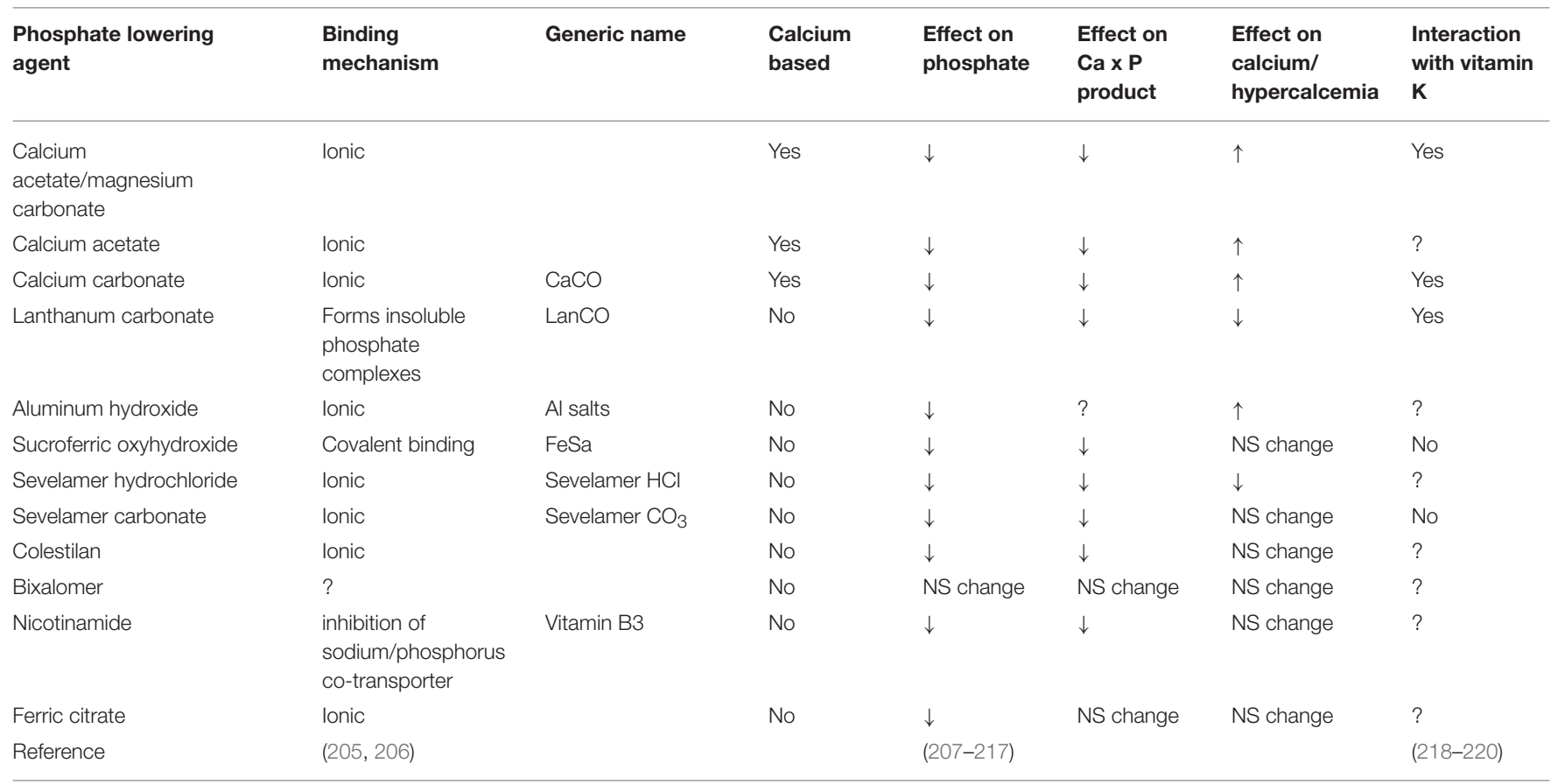

Ca, Calcium; P, Phosphorous.

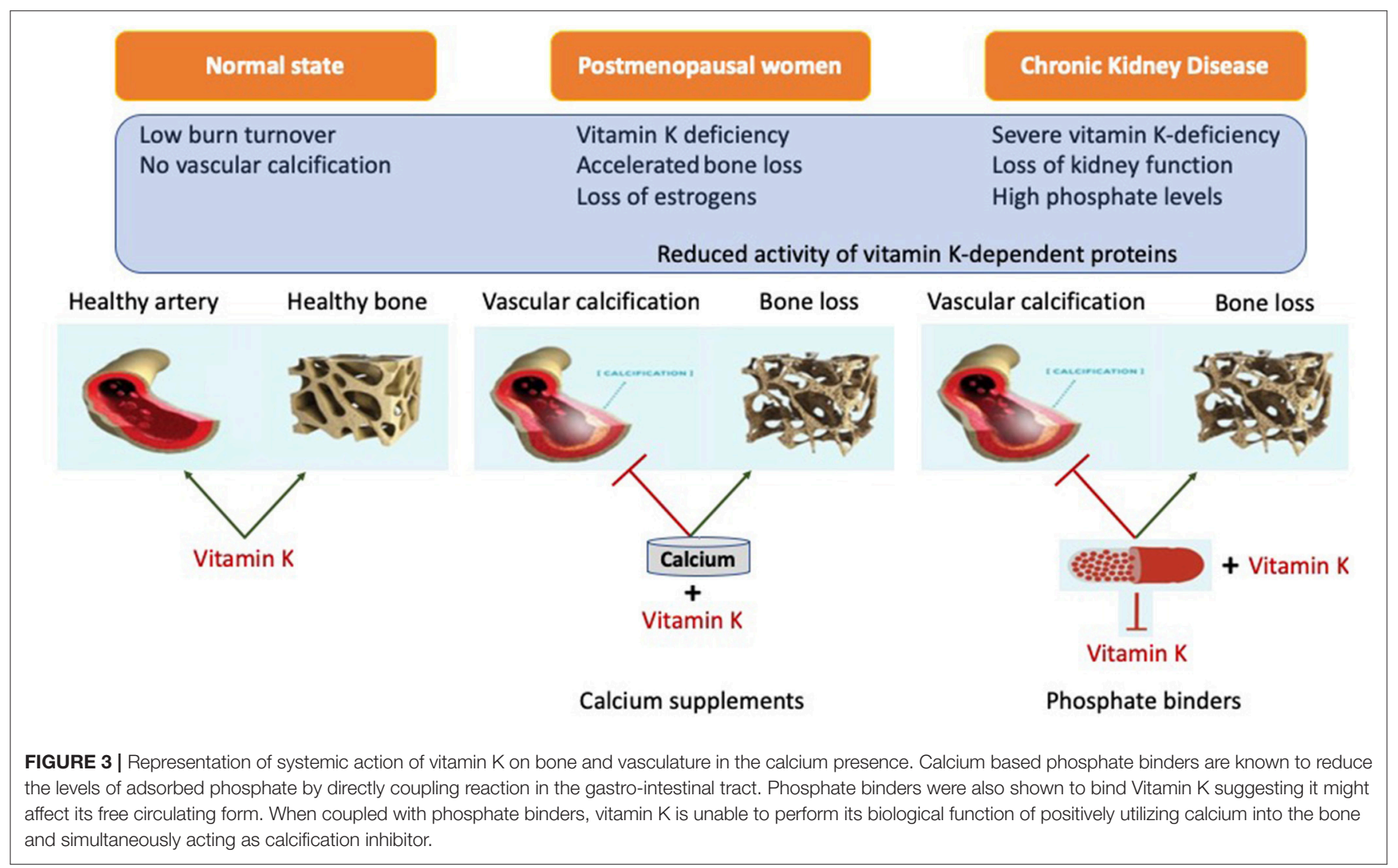


with placebo-treated osteoporotic patients (232). Moreover, both MK-4 and MK-7 supplementation resulted in an increase of cOC and a decrease of ucOC and improved BMD $(229,233-$ 238).

Besides its beneficial effects on bone health, high intake of MK-7 successfully blocked age-related vascular stiffening (239) in post-menopausal women. Moreover, MK-7 was better than placebo at reducing severe aortic calcification and relative risk of coronary heart disease $(208,240)$. Ongoing clinical trials will evaluate its effectiveness in reducing vascular calcification in patients with coronary artery disease (241). In a crosssectional study, nutritional long-chain menaquinone intake was associated with decreased coronary calcification in postmenopausal women $(240,242)$. Moreover, MK-7 improved arterial stiffness and elastic properties of the carotid artery in a healthy postmenopausal woman (20) and improved vitamin $\mathrm{K}$ status in dialysis patients by decreasing inactive levels of MGP by daily supplementation (24). In another randomized clinical study, K1 supplementation slowed the progression of CAC in healthy older adults with preexisting CAC, demonstrating the potential efficacy of vitamin $\mathrm{K}$ treatment for vascular calcification. Inactive MGP (dp-ucMGP) has been correlated with severity of $\mathrm{CKD}$ and is positively associated with amount of vascular calcification (24, 224, 243, 244). MK-7 (MenaQ7) supplementation in patients with CKD3-5 significantly reduced circulating levels of dp-ucMGP (24).

Collectively, these data imply that vitamin $\mathrm{K}$ could serve as complementary nutrient to calcium (and vitamin D) to protect from increased risk for vascular calcification thereby allowing more safe treatment of osteoporosis. Vitamin K supplementation in post-menopausal patients appeared beneficial in combination with calcium and vitamin D3 for bone health and vasculature (239). The combination of vitamin $\mathrm{K}$ and calcium could reduce risk on post-menopausal bone and simultaneously prevent vascular calcification, thereby aiding the beneficial effects of

\section{REFERENCES}

1. Persy V, D'Haese P. Vascular calcification and bone disease: the calcification paradox. Trends Mol Med. (2009) 15:405-16. doi: 10.1016/j.molmed.2009.07.001

2. Von der Recke P, Hansen MA, Hassager C. The association between low bone mass at the menopause and cardiovascular mortality. Am J Med. (1999) 106:273-8. doi: 10.1016/S0002-9343(99)00028-5

3. Farhat GN, Newman AB, Sutton-Tyrrell K, Matthews KA, Boudreau R, Schwartz AV, et al. The association of bone mineral density measures with incident cardiovascular disease in older adults. Osteoporos Int. (2007) 18:999-1008. doi: 10.1007/s00198-007-0338-8

4. Mussolino ME, Madans JH, Gillum RF. Bone mineral density and stroke. Stroke (2003) 34:E20-2. doi: 10.1161/01.STR.0000065826.23815.A5

5. Kado DM, Browner WS, Blackwell T, Gore R, Cummings SR. Rate of bone loss is associated with mortality in older women: a prospective study. J Bone Miner Res. (2000) 15:1974-80. doi: 10.1359/jbmr.2000.15.10.1974

6. Trivedi DP, Khaw KT. Bone mineral density at the hip predicts mortality in elderly men. Osteoporos Int. (2001) 12:259-65. doi: 10.1007/s001980170114

7. Aloia J, Bojadzievski T, Yusupov E, Shahzad G, Pollack S, Mikhail M, et al. The relative influence of calcium intake and vitamin D status on calcium in bone and preventing the negatively associated vascular effects of supplemental calcium intake.

\section{CONCLUSIONS}

To date, calcium supplements are the most commonly used non-prescription drug to treat age-related bone loss. Also, in patients suffering from chronic kidney disease, calcium-based phosphate binders are commonly prescribed. However, the rising concern of side-effects from calcium supplementation illustrates a clinical dilemma: supplementation of calcium-either with or without vitamin $\mathrm{D}$-comes at the price of increased risk of vascular calcification. Clinical studies demonstrate that increased intake of vitamin $\mathrm{K}$ could be a promising complementary nutrient in supporting both bone health and protecting vascular calcification. Thereby it can increase safety of current treatments of osteoporosis and provide an escape from the calcium paradox. Future clinical trials should be carried out to confirm the feasibility of such combination.

\section{AUTHOR CONTRIBUTIONS}

All authors listed have made a substantial, direct and intellectual contribution to the work, and approved it for publication. GW wrote the manuscript. MV wrote the manuscript and was responsible for the final version. LS wrote the manuscript, supervised writing process and was responsible for the final version.

\section{FUNDING}

This work was supported by funding from the Norwegian Research Council (Project 241584) and NattoPharma ASA. Research from LS is in part funded via the European Union's Horizon 2020 research and innovation programme under the Marie Skłodowska-Curie grant agreement No. 722609.

serum parathyroid hormone and bone turnover biomarkers in a doubleblind, placebo-controlled parallel group, longitudinal factorial design. J Clin Endocrinol Metab. (2010) 95:3216-24. doi: 10.1210/jc.2009-1294

8. Tai V, Leung W, Grey A, Reid IR, Bolland MJ. Calcium intake and bone mineral density: systematic review and meta-analysis. BMJ (2015) 351:h4183. doi: 10.1136/bmj.h4183

9. Bueno AL, Czepielewski MA. The importance for growth of dietary intake of calcium and vitamin D. Pediatr J. (2008) 84:386-94. doi: 10.2223/JPED.1816

10. Gennari C. Calcium and vitamin D nutrition and bone disease of the elderly. Pub Health Nutr. (2001) 4:2. doi: 10.1079/PHN2001140

11. J.-Zhao G, X.-Zeng T, Wang J, Liu L. Association between calcium or vitamin $\mathrm{D}$ supplementation and fracture incidence in community-dwelling older adults a systematic review and meta-analysis. JAMA (2017) 318:2466-82. doi: 10.1001/jama.2017.19344

12. Bolland MJ, Avenell A, Baron JA, Grey A, MacLennan GS, Gamble GD, et al. Effect of calcium supplements on risk of myocardial infarction and cardiovascular events: meta-analysis. BMJ (2010) 341:c3691. doi: 10.1136/bmj.c3691

13. Anderson JJ, Kruszka B, Delaney JA, He K, Burke GL, Alonso A, et al. Calcium intake from diet and supplements and the risk of coronary artery calcification and its progression among older adults: 10-year follow-up of 
the multi-ethnic study of atherosclerosis (MESA). J Am Heart Assoc. (2016) 5:1-14. doi: 10.1161/JAHA.116.003815

14. Spence LA, Weaver CM. Calcium intake, vascular calcification, and vascular disease. Nutr Rev. (2013) 71:15-22. doi: 10.1111/nure.12002

15. Karp HJ, Ketola ME, Lamberg-Allardt CJE. Acute effects of calcium carbonate, calcium citrate and potassium citrate on markers of calcium and bone metabolism in young women. Br J Nutr. (2009) 102:1341-7. doi: 10.1017/S0007114509990195

16. Heaney RP, Dowell MS, Bierman J, Hale CA, Bendich A. Absorbability and cost effectiveness in calcium supplementation. J Am Coll Nutr. (2001) 20:239-46. doi: 10.1080/07315724.2001.10719038

17. Carroll R, Matfin G. Endocrine and metabolic emergencies: hypocalcaemia. Ther Adv Endocrinol Metab. (2010) 1:29-33. doi: 10.1177/2042018810366494

18. Felsenfeld AJ, Levine BS. Calcitonin, the forgotten hormone: does it deserve to be forgotten?. Clin Kidney J. (2015) 8:180-7. doi: 10.1093/ckj/sfv011

19. Knapen MH, Schurgers LJ, Vermeer C. Vitamin K2 supplementation improves hip bone geometry and bone strength indices in postmenopausal women. Osteoporos Int. (2007) 18:963-72. doi: 10.1007/s00198-007-0337-9

20. Knapen MH, Braam LA, Drummen NE, Bekers O, Hoeks AP, Vermeer C. Menaquinone-7 supplementation improves arterial stiffness in healthy postmenopausal women. Thromb Haemost. (2015) 113:1135-44. doi: 10.1160/TH14-08-0675

21. Maas AH, van der Schouw YT, Beijerinck D, Deurenberg JJ, Mali WP, Grobbee DE, et al. Vitamin $\mathrm{K}$ intake and calcifications in breast arteries. Maturitas (2007) 56:273-9. doi: 10.1016/j.maturitas.2006.09.001

22. Theuwissen E, Magdeleyns EJ, Braam LA, Teunissen KJ, Knapen MH, Binnekamp IA, et al. Vitamin $\mathrm{K}$ status in healthy volunteers. Food Funct. (2014) 5:229-34. doi: 10.1039/C3FO60464K

23. Cranenburg EC, Schurgers LJ, Uiterwijk HH, Beulens JW, Dalmeijer GW, Westerhuis $\mathrm{R}$, et al. Vitamin $\mathrm{K}$ intake and status are low in hemodialysis patients. Kidney Int. (2012) 82:605-10. doi: 10.1038/ki.2012.191

24. Westenfeld R, Krueger T, Schlieper G, Cranenburg EC, Magdeleyns EJ, Heidenreich S, et al. Effect of vitamin K2supplementation on functional vitamin $\mathrm{K}$ deficiency in hemodialysis patients: a randomized trial. $\mathrm{Am} \mathrm{J}$ Kidney Dis. (2012) 59:186-95. doi: 10.1053/j.ajkd.2011.10.041

25. Lips P, Courpron P, Meunier PJ. Mean wall thickness of trabecular bone packets in the human iliac crest: changes with age. Calcif Tissue Res. (1978) 26:13-7. doi: 10.1007/BF02013227

26. Parfitt M, Mathews HE, Villanueva R, Kleerekoper M, Frame B, Rao DS. Relationships between surface, volume, and thcikness of iliac trabecular bone in aging and in osteoporosis. J Clin Invest. (1983) 72:1396-409. doi: 10.1172/JCI111096

27. Courpron P, Meunier P, Vignon G. [Dynamics of bone remodeling explained by Harold Frost. Theory of the B. M.U. (basic multicellular unit)]. Nouv Presse Med. (1975) 4:421-4.

28. Yang YQ, Tan YY, Wong R, Wenden A, Zhang LK, Rabie ABM. The role of vascular endothelial growth factor in ossification. Int J Oral Sci. (2012) 4:64-8. doi: $10.1038 /$ ijos.2012.33

29. Liu TM, Lee EH. Transcriptional regulatory cascades in runx2dependent bone development. Tissue Eng Part B Rev. (2013) 19:254-63. doi: 10.1089/ten.teb.2012.0527

30. Kampen WU, Claassen H, Kirsch T. Mineralization and osteogenesis in the human first rib cartilage. Ann Anat. (1995) 177:171-7. doi: 10.1016/S0940-9602(11)80069-5

31. Maes C, Kobayashi T, Selig MK, Torrekens S, Roth SI, Mackem S, et al. Osteoblast precursors, but not mature osteoblasts, move into developing and fractured bones along with invading blood vessels. Dev Cell (2010) 19:329-44. doi: 10.1016/j.devcel.2010.07.010

32. Ono N, Ono W, Mizoguchi T, Nagasawa T, Frenette PS, Kronenberg HM. Vasculature-associated cells expressing nestin in developing bones encompass early cells in the osteoblast and endothelial lineage. Dev Cell (2014) 29:330-9. doi: 10.1016/j.devcel.2014.03.014

33. Gilbert SF. Osteogenesis: The Development of Bones. In: Developmental Biology. 6th ed. (2000). Available online at: http://www.ncbi.nlm.nih.gov/ books/NBK10056/.

34. Sims NA, Martin TJ. Coupling the activities of bone formation and resorption: a multitude of signals within the basic multicellular unit. Bonekey Rep. (2014) 3:1-10. doi: 10.1038/bonekey.2013.215
35. Udagawa N, Takito J, Suda T. [Mechanism of acid production and secretion by osteoclasts]. Nihon Rinsho. (1992) 50:2133-8.

36. Gundberg CM, Weinstein RS. Multiple immunoreactive forms of osteocalcin in uremic serum. J Clin Invest. (1986) 77:1762-7. doi: 10.1172/JCI112499

37. Izumi Y, Matsumoto K, Ozawa Y, Kasamaki Y, Shinndo A, Ohta M, et al. Effect of age at menopause on blood pressure in postmenopausal women. Am J Hypertens. (2007) 20:1045-50. doi: 10.1016/j.amjhyper.2007.04.019

38. Dosi R, Bhatt N, Shah P, Patell R. Cardiovascular disease and menopause. J Clin Diagnostic Res. (2014) 8:62-4. doi: 10.7860/JCDR/2014/6457.4009

39. Davis SR, Lambrinoudaki I, Lumsden M, Mishra GD, Pal L, Rees M, et al. Menopause. Nat Rev Dis Prim. (2015) 1:15004. doi: 10.1038/nrdp.2015.4

40. Kanis JA, Melton LJ III, Christiansen C, Johnston CC, Khaltaev N. The diagnosis of osteoporosis. J Bone Miner Res. (1994) 9:1137-41.

41. Clarke NM, Page JE. Vitamin D deficiency. Curr Opin Pediatr. (2012) 24:46-9. doi: 10.1097/MOP.0b013e32834ec8eb.

42. Holick MF, MacLaughlin JA, Clark MB, Holick SA, Potts JT, Anderson RR, et al. Photosynthesis of previtamin D3 in human skin and the physiologic consequences. Science (1980) 210:203-5. doi: 10.1126/science.6251551

43. Holick MF. Vitamin D status: measurement, interpretation and clinical application. Ann Epidemiol. (2009) 19:73-8. doi: 10.1016/j.annepidem.2007.12.001

44. Dusso AS, Brown AJ, Slatopolsky E. Vitamin D. Am J Physiol Ren Physiol. (2005) 289:F8-28. doi: 10.1152/ajprenal.00336.2004

45. DeLuca HF. Overview of general physiologic features and functions of vitamin D. Am J Clin Nutr. (2004) 80(Suppl. 6):1689S-96S. doi: $10.1093 /$ ajcn/80.6.1689S

46. Heaney RP, Dowell MS, Hale CA, Bendich A. Calcium absorption varies within the reference range for serum 25-hydroxyvitamin D. J Am Coll Nutr. (2003) 22:142-6. doi: 10.1080/07315724.2003.10719287

47. Owen TA, Aronow MS, Barone LM, Bettencourt B, Stein GS, Lian JB. Pleiotropic effects of vitamin D on osteoblast gene expression are related to the proliferative and differentiated state of the bone cell phenotype: dependency upon basal levels of gene expression, duration of exposure, and bone matrix competency in norma. Endocrinology (1991) 128:1496-504. doi: 10.1210/endo-128-3-1496

48. Neve A, Corrado A, Cantatore FP. Osteocalcin: skeletal and extra-skeletal effects. J Cell Physiol. (2013) 228:1149-53. doi: 10.1002/jcp.24278

49. Je SH, Joo NS, Choi BH, Kim KM, Kim BT, Park SB, et al. Vitamin K supplement along with vitamin $\mathrm{D}$ and calcium reduced serum concentration of undercarboxylated osteocalcin while increasing bone mineral density in Korean postmenopausal women over sixty-years-old. J Korean Med Sci. (2011) 26:1093-98. doi: 10.3346/jkms.2011.26.8.1093

50. Shimada T, Yamazaki Y, Takahashi M, Hasegawa H, Urakawa I, Oshima T, et al. Vitamin D receptor-independent FGF23 actions in regulating phosphate and vitamin D metabolism. Am J Physiol Renal Physiol. (2005) 289:F1088-95. doi: 10.1152/ajprenal.00474.2004

51. Koenig KG, Lindberg JS, Zerwekh JE, Padalino PK, Cushner HM, Copley JB. Free and total 1,25-dihydroxyvitamin $\mathrm{D}$ levels in subjects with renal disease. Kidney Int. (1992) 41:161-5. doi: 10.1038/ki.1992.22

52. Filipov JJ, Zlatkov BK, Dimitrov EP, Svinarov D. Relationship between vitamin $\mathrm{D}$ status and immunosuppressive therapy in kidney transplant recipients. Biotechnol Biotechnol Equip. (2015) 29:331-5. doi: 10.1080/13102818.2014.995415

53. Ngai M, Lin V, Wong HC, Vathsala A, How P. Vitamin D status and its association with mineral and bone disorder in a multi-ethnic chronic kidney disease population. Clin Nephrol. (2014) 82:231-9. doi: 10.5414/CN108182

54. Wilson PW, Kauppila LI, O’Donnell CJ, Kiel DP, Hannan M, Polak JM, et al. Abdominal aortic calcified deposits are an important predictor of vascular morbidity and mortality. Circulation (2001) 103:1529-34. doi: 10.1161/01.CIR.103.11.1529

55. Okuno S, Ishimura E, Kitatani K, Fujino Y, Kohno K, Maeno Y, et al. Presence of abdominal aortic calcification is significantly associated with all-cause and cardiovascular mortality in maintenance hemodialysis patients. Am J Kidney Dis. (2007) 49:417-25. doi: 10.1053/j.ajkd.2006.12.017

56. Reynolds JL, Joannides AJ, Skepper JN, McNair R, Schurgers LJ, Proudfoot D, et al. Human vascular smooth muscle cells undergo vesiclemediated calcification in response to changes in extracellular calcium and phosphate concentrations: a potential mechanism for accelerated 
vascular calcification in ESRD. J Am Soc Nephrol. (2004) 15:2857-67. doi: 10.1097/01.ASN.0000141960.01035.28

57. Kapustin AN, Chatrou ML, Drozdov I, Zheng Y, Davidson SM, Soong D, et al. Vascular smooth muscle cell calcification is mediated by regulated exosome secretion. Circ Res. (2015) 116:1312-23. doi: 10.1161/CIRCRESAHA.116.305012

58. Laurent S, Boutouyrie P, Asmar R, Gautier I, Laloux B, Guize L, et al. Aortic stiffness is an independent predictor of all-cause and cardiovascular mortality in hypertensive patients. Hypertension (2001) 37:1236-41. doi: 10.1161/01.HYP.37.5.1236

59. Blacher J, Asmar R, Djane S, London GM, Safar ME, London M. Aortic pulse wave velocity as a marker of cardiovascular risk in hypertensive patients. Methods (1999) 33:1111-7.

60. Rezg R, Barreto FC, Barreto DV, Liabeuf S, Drüeke TB, Massy ZA. Inhibitors of vascular calcification as potential therapeutic targets. J Nephrol. (2011) 24:416-27. doi: 10.5301/JN.2011.8420

61. Rensen SSM, Doevendans PAFM, van Eys GJJM. Regulation and characteristics of vascular smooth muscle cell phenotypic diversity. Neth Heart J. (2007) 15:100-8. doi: 10.1007/BF03085963

62. Owens GK, Kumar MS, Wamhoff BR. Molecular regulation of vascular smooth muscle cell differentiation in development and disease (2004) 84:767-801. doi: 10.1152/physrev.00041.2003

63. Iyemere VP, Proudfoot D, Weissberg PL, Shanahan CM. Vascular smooth muscle cell phenotypic plasticity and the regulation of vascular calcification. J Intern Med. (2006) 260:192-210. doi: 10.1111/j.1365-2796.2006.01692.x

64. Houben E, Neradova A, Schurgers LJ, Vervloet M. The influence of phosphate, calcium and magnesium on matrix Gla-protein and vascular calcification: a systematic review. G Ital Nefrol. (2016) 33:6.

65. Vajen T, Benedikter BJ, Heinzmann ACA, Vasina EM, Henskens $\mathrm{Y}$, Parsons $\mathrm{M}$, et al. Platelet extracellular vesicles induce a proinflammatory smooth muscle cell phenotype. J Extracell Vesicles (2017) 6:1. doi: 10.1080/20013078.2017.1322454

66. Jono S, McKee MD, Murry CE, Shioi A, Nishizawa Y, Mori K, et al. Phosphate regulation of vascular smooth muscle cell calcification. Circ Res. (2000) 87:E10-7. doi: 10.1161/01.RES.87.7.e10

67. Steitz SA, Speer MY, Curinga G, Yang HY, Haynes P, Aebersold R, et al. Smooth muscle cell phenotypic transition associated with calcification: upregulation of $\mathrm{Cbfa} 1$ and downregulation of smooth muscle lineage markers. Circ Res. (2001) 89:1147-54. doi: 10.1161/hh2401.101070

68. Alves RDAM, Eijken M, van de Peppel J, van Leeuwen JPTM. Calcifying vascular smooth muscle cells and osteoblasts: independent cell types exhibiting extracellular matrix and biomineralization-related mimicries. BMC Genomics (2014) 15:965. doi: 10.1186/1471-2164-15-965

69. Willems BA, Furmanik M, Caron MMJ, Chatrou MLL, Kusters DHM, Welting TJM, et al. Ucma/GRP inhibits phosphate-induced vascular smooth muscle cell calcification via SMAD-dependent BMP signalling. Sci Rep. (2018) 8:1-11. doi: 10.1038/s41598-018-23353-y

70. Lanzer P, Boehm M, Sorribas V, Thiriet M, Janzen J, Zeller T, et al. Medial vascular calcification revisited: review and perspectives. Eur Heart J. (2014) 35:1515-25. doi: 10.1093/eurheartj/ehu163

71. Block GGA, Klassen PS, Lazarus JM, Ofsthum N, Lowrie EG, Chertow GM. Mineral metabolism, mortality, and morbidity ian maintenance hemodialysis. J Am Soc Nephrol. (2004) 15:2208-18. doi: 10.1097/01.ASN.0000133041.27682.A2

72. Taniguchi M, Fukagawa M, Fujii N, Hamano T, Shoji T, Yokoyama K, et al. Serum phosphate and calcium should be primarily and consistently controlled in prevalent hemodialysis patients. Ther Apher Dial. (2013) 17:221-8. doi: 10.1111/1744-9987.12030

73. El-Abbadi MM, Pai AS, Leaf EM, Yang HY, Bartley BA, Quan KK, et al. Phosphate feeding induces arterial medial calcification in uremic mice: role of serum phosphorus, fibroblast growth factor23, and osteopontin. Kidney Int. (2009) 75:1297-307. doi: 10.1038/ki. 2009.83

74. Palit S, Kendrick J. Vascular calcification in chronic kidney disease: role of disordered mineral metabolism. Curr Pharm Des. (2014) 20:5829-33. doi: 10.2174/1381612820666140212194926

75. Chamley JH, Campbell GR, Burnstock G. Dedifferentiation, redifferentiation and bundle formation of smooth muscle cells in tissue culture: the influence of cell number and nerve fibers. J Embryol Exp Morphol. (1974) 32:297-323.
76. Kestenbaum B, Sampson JN, Rudser KD, Patterson DJ, Seliger SL, Young B, et al. Serum phosphate levels and mortality risk among people with chronic kidney disease. J Am Soc Nephrol. (2005) 16:520-8. doi: 10.1681/ASN.2004070602

77. Shanahan CM, Crouthamel MH, Kapustin A, Giachelli CM. Arterial calcification in chronic kidney disease: key roles for calcium and phosphate. Circ Res. (2012) 109:697-711. doi: 10.1161/CIRCRESAHA.110.234914

78. Rajamannan NM, Subramaniam M, Rickard D, Stock SR, Donovan J, Springett $M$, et al. Human aortic valve calcification is associated with an osteoblast phenotype. Circulation (2003) 107:2181-4. doi: 10.1161/01.CIR.0000070591.21548.69

79. Hunt JL, Fairman R, Mitchell ME, Carpenter JP, Golden M, Khalapyan T, et al. Bone formation in carotid plaques: a clinicopathological study. Stroke (2002) 33:1214-9. doi: 10.1161/01.STR.0000013741.41309.67

80. Crowley ST, Ray CJ, Nawaz D, Majack RA, Horwitz LD. Multiple growth factors are released from mechanically injured vascular smooth muscle cells. Am J Physiol. (1995) 269:H1641-7.

81. Bowen-Pope DF, Raines EW. History of discovery: platelet-derived growth factor. Arterioscler Thromb Vasc Biol. (2011) 31:2397-401. doi: 10.1161/ATVBAHA.108.179556

82. Schollmanns C, Grugel R, Tatje D, Hoppe J, Folkman J, Marmé D, et al. Basic Fibroblast Growth Factor Modulates the Mitogenic Potency of the Plateletderived Growth Factor ( PDGF) Isoforms by Specific Up- regulation of the PDGF a! Receptor in Vascular Smooth Muscle Cells. J Biol Chem. (1992) 267:18032-9.

83. Shea B, Wells G, Cranney A, Zytaruk N, Robinson V, Griffith L et al. VII. Meta-analysis of calcium supplementation for the prevention of postmenopausal osteoporosis. Endocr Rev. (2002) 23:552-9. doi: 10.1210/er.2001-7002

84. Silk LN, Greene DA, Baker MK. The effect of calcium or calcium and vitamin D supplementation on bone mineral density in healthy males: a systematic review and meta-analysis. Int J Sport Nutr Exerc Metab. (2015) 25:510-24. doi: 10.1123/ijsnem.2014-0202

85. Tang BM, Eslick GD, Nowson C, Smith C, Bensoussan A. Use of calcium or calcium in combination with vitamin $\mathrm{D}$ supplementation to prevent fractures and bone loss in people aged 50 years and older: a meta-analysis. Lancet (2007) 370:657-66. doi: 10.1016/S0140-6736(07)61342-7

86. Rozenberg S, Body JJ, Bruyère O, Bergmann P, Brandi ML, Cooper C, et al. Effects of dairy products consumption on health: benefits and beliefs-a commentary from the belgian bone club and the european society for clinical and economic aspects of osteoporosis, osteoarthritis and musculoskeletal diseases. Calcif Tissue Int. (2016) 98:1-17. doi: 10.1007/s00223-015-0062-x

87. Reid IR, Mason B, Horne A, Ames R, Reid HE, Bava U, et al. Randomized controlled trial of calcium in healthy older women. Am J Med. (2006) 119:777-85. doi: 10.1016/j.amjmed.2006.02.038

88. Qing Zhang Z, ming Ma X, wu Huang Z, guang Yang X, ming Chen $Y$, xiang Su Y. Effects of milk salt supplementation on bone mineral gain in pubertal Chinese adolescents: A 2-year randomized, double-blind, controlled, doseresponse trial. Bone (2014) 65:69-76. doi: 10.1016/j.bone.2014.05.007

89. Raffield LM, Agarwal S, Cox AJ, Hsu FC, Carr JJ, Freedman BI, et al. Cross-sectional analysis of calcium intake for associations with vascular calcification and mortality in individuals with type 2 diabetes from the Diabetes Heart Study. Am J Clin Nutr. (2014) 100:1029-35. doi: 10.3945/ajcn.114.090365

90. Bostick RM, Kushi LH, Wu Y, Meyer KA, Sellers TA, Folsom AR. Relation of calcium, vitamin $\mathrm{D}$, and dairy food intake to ischemic heart disease mortality among postmenopausal women. Am J Epidemiol. (1999) 149:15161. doi: 10.1093/oxfordjournals.aje.a009781

91. Hyder JA, Allison MA, Criqui MH, Wright CM. Association between systemic calcified atherosclerosis and bone density. Calcif Tissue Int. (2007) 80:301-6. doi: 10.1007/s00223-007-9004-6

92. Ross AC, Manson JE, Abrams SA, Aloia JF, Brannon PM, Clinton SK, et al. The 2011 report on dietary reference intakes for calcium and vitamin $\mathrm{d}$ from the institute of medicine: what clinicians need to know. J Clin Endocrinol Metab. (2011) 96:53-8. doi: 10.1210/jc.2010-2704

93. "Calcium Equivalents." Online. Available online at: http://www-users.med. cornell.edu/ spon/picu/calc/cacalc.htm (Accessed: 17-Apr-2018).

94. Straub DA. Nutrition in clinical practice calcium supplementation in clinical practice : a review of. forms, doses, and indications. Nutr Clin Pract. (2007) 286-96. doi: 10.1177/0115426507022003286 
95. " $10 \%$ Calcium Chloride (calcium chloride) dose, indications, adverse effects, interactions... from PDR.net." Online]. Available online at: http://www. pdr.net/drug-summary/10--Calcium-Chloride-calcium-chloride- 3148. Accessed: 17-Apr-2018].

96. Heller HJ, Greer LG, Haynes SD, Poindexter JR, Pak CY. Pharmacokinetic and pharmacodynamic comparison of two calcium supplements in postmenopausal women. J Clin Pharmacol. (2000) 40:1237-44.

97. Heaney RP, Rafferty K, Dowell MS, Bierman J. Calcium fortification systems differ in bioavailability. J Am Diet Assoc. (2005) 105:807-9. doi: 10.1016/j.jada.2005.02.012

98. Heaney RP. Research communication: quantifying human calcium absorption using pharmacokinetic methods. J Nutr. (2003) 133:1224-6. doi: $10.1093 /$ jn/133.4.1224

99. Heaney RP, Dowell MS, Barger-Lux MJ. Absorption of calcium as the carbonate and citrate salts, with some observations on method. Osteoporos Int. (1999) 9:19-23. doi: 10.1007/s001980050111

100. Voinescu A, Martin KJ. Chapter 19: calcium, phosphate, PTH, vitamin D and FGF-23 in chronic kidney disease. In: Kopple JD, Massry SG, Kalantar-Zadeh K, editors. Nutritional Management of Renal Disease. 3rd edn. St. Louis, MO: Academic Press (2013). p. 263-83.

101. Kressel G. Bioavailability and solubility of different calcium-salts as a basis for calcium enrichment of beverages. Food Nutr Sci. (2010) 1:53-8. doi: 10.4236/fns.2010.12009

102. Tondapu P, Provost D, Adams-Huet B, Sims T, Chang C, Sakhaee $\mathrm{K}$. Comparison of the absorption of calcium carbonate and calcium citrate after roux-en-Y gastric bypass. Obes Surg. (2009) 19:1256-61. doi: 10.1007/s11695-009-9850-6

103. Samozai MN, Kulkarni AK. Do calcium supplements increase serum and urine calcium levels in post-menopausal women?. J Nutr Health Aging. (2015) 19:537-41. doi: 10.1007/s12603-014-0532-2

104. Burckhardt P. Potential negative cardiovascular effects of calcium supplements. Osteoporos Int. (2011) 22:1645-7. doi: 10.1007/s00198-011-1602-5

105. Chung M, Tang AM, Fu Z, Wang DD, Newberry SJ. Calcium Intake and cardiovascular disease risk: an updated systematic review and meta-analysis. Ann Intern Med. (2016) 165:856-66. doi: 10.7326/M16-1165

106. Kopecky SL, Bauer DC, Gulati M, Nieves JW, Singer AJ, Toth PP, et al. Lack of evidence linking calcium with or without vitamin $\mathrm{d}$ supplementation to cardiovascular disease in generally healthy adults: a clinical guideline from the national osteoporosis foundation and the american society for preventive cardiology. Ann Intern Med. (2016) 165:867-8. doi: 10.7326/M16-1743

107. Ethgen O, Hiligsmann M, Burlet N, Reginster JY. Cost-effectiveness of personalized supplementation with vitamin D-rich dairy products in the prevention of osteoporotic fractures. Osteoporos Int. (2016) 27:301-8. doi: 10.1007/s00198-015-3319-3

108. Jackson RD, LaCroix AZ, Gass M, Wallace RB, Robbins J, Lewis CE, et al. Calcium plus vitamin D supplementation and the risk of fractures. $N$ Engl J Med. (2006) 354:669-83. doi: 10.1056/NEJMoa055218

109. Moe S, Drüeke T, Cunningham J, Goodman W, Martin K, Olgaard K, et al. Definition, evaluation, and classification of renal osteodystrophy: a position statement from kidney disease: improving global outcomes (KDIGO). Kidney Int. (2006) 69:1945-53. doi: 10.1038/sj.ki.5000414

110. Alem AM, Sherrard DJ, Gillen DL, Weiss NS, Beresford SA, Heckbert SR, et al. Increased risk of hip fracture among patients with end-stage renal disease. Kidney Int. (2000) 58:396-99. doi: 10.1046/j.1523-1755.2000.00178.x

111. Wakasugi M, Kazama JJ, Taniguchi M, Wada A, Iseki K, Tsubakihara Y, et al. Increased risk of hip fracture among Japanese hemodialysis patients. J Bone Miner Metab. (2013) 31:315-321. doi: 10.1007/s00774-012-0411-z

112. Rodríguez-García M, Gómez-Alonso C, Naves-Díaz M, Diaz-Lopez JB, DiazCorte C, Cannata-Andía JB, et al. Vascular calcifications, vertebral fractures and mortality in haemodialysis patients. Nephrol Dial Transplant. (2009) 24:239-46. doi: 10.1093/ndt/gfn466

113. Block G, Hulbert-Shearon T, Levin N, Port F. Association of serum phosphorus and calcium $\mathrm{x}$ phosphate product with mortality risk in chronic hemodialysis patients: a national study. Am J Kidney Dis. (1998) 31:607-17. doi: 10.1053/ajkd.1998.v31.pm9531176

114. Tentori F, Blayney MJ, Albert JM, Gillespie BW, Kerr PG, Bommer $\mathrm{J}$, et al. Mortality risk for dialysis patients with different levels of serum calcium, phosphorus, and PTH: the dialysis outcomes and practice patterns study (DOPPS). Am J Kidney Dis. (2008) 52:519-30. doi: 10.1053/j.ajkd.2008.03.020

115. Six I, Maizel J, Barreto FC, Rangrez AY, Dupont S, Slama M, et al. Effects of phosphate on vascular function under normal conditions and influence of the uraemic state. Cardiovasc Res. (2012) 96:130-9. doi: 10.1093/cvr/cvs240

116. Kandula P, Dobre M, Schold JD, Schreiber MJ, Mehrotra R, Navaneethan SD. Vitamin D Supplementation in chronic kidney disease: a systematic review and meta-analysis of observational studies and randomized controlled trials. Clin J Am Soc Nephrol. (2011) 6:50-62. doi: 10.2215/CJN.03940510

117. Stenvinkel P, Carrero JJ, Axelsson J, Lindholm B, Heimbürger O, Massy Z. Emerging biomarkers for evaluating cardiovascular risk in the chronic kidney disease patient: how do new pieces fit into the uremic puzzle?. Clin J Am Soc Nephrol. (2008) 3:505-21. doi: 10.2215/CJN.03670807

118. Raisz LG. pathogenesis of osteoporosis : concepts, conflicts, and prospects. Sci Med. (2005) 115:3318-25. doi: 10.1172/JCI27071

119. Karaguzel G, Holick MF. Diagnosis and treatment of osteopenia. Rev Endocr Metab Disord. (2010) 11:237-51. doi: 10.1007/s11154-010-9154-0

120. ["Healthy Bones The National Osteoporosis Society." Online]. Available online at: https://nos.org.uk/about-osteoporosis/your-bone-strength/abalanced-diet-for-bones/. Accessed: 06-Jun-2018].

121. Kantor ED, Rehm CD, Du M, White E, Giovannucci EL. Trends in Dietary Supplement Use Among US Adults From 1999-2012. JAMA (2016) 316:1464. doi: 10.1001/jama.2016.14403

122. Bading H. Nuclear calcium signalling in the regulation of brain function. Nat Rev Neurosci. (2013) 14:593. doi: 10.1038/nrn3531

123. Orrenius S, Gogvadze V, Zhivotovsky B. Calcium and mitochondria in the regulation of cell death. Biochem Biophys Res Commun. (2015) 460:72-81. doi: 10.1016/j.bbrc.2015.01.137

124. Minisola S, Pepe J, Piemonte S, Cipriani C. The diagnosis and management of hypercalcaemia. BMJ (2015) 350:h2723. doi: 10.1136/bmj.h2723.

125. Weisman SM. The calcium connection to bone health across a woman's lifespan: a roundtable. J Reprod Med. (2005) 50(Suppl. 11):879-84.

126. Ivey KL, Lewis JR, Hodgson JM, Zhu K, Dhaliwal SS, Thompson $\mathrm{PL}$, et al. Association between yogurt, milk, and cheese consumption and common carotid artery intima-media thickness and cardiovascular disease risk factors in elderly women. Am J Clin Nutr. (2011) 6:234-9. doi: 10.3945/ajen.111.014159

127. Tanaka S, Uenishi K, Yamazaki Y, Kuroda T, Shiraki M. Low calcium intake is associated with high plasma homocysteine levels in postmenopausal women. J Bone Miner Metab. (2014) 32:317-23. doi: 10.1007/s00774-013-0499-9

128. Michaelsson K, Melhus H, Warensjo Lemming E, Wolk A, Byberg L. Long term calcium intake and rates of all cause and cardiovascular mortality: community based prospective longitudinal cohort study. BMJ (2013) 346:f228. doi: 10.1136/bmj.f228

129. Li K, Kaaks R, Linseisen J, Rohrmann S. Associations of dietary calcium intake and calcium supplementation with myocardial infarction and stroke risk and overall cardiovascular mortality in the Heidelberg cohort of the European Prospective Investigation into Cancer and Nutrition study (EPICHei. Heart (2012) 98:920-5. doi: 10.1136/heartjnl-2011-301345

130. Khan B, Nowson CA, Daly RM, English DR, Hodge AM, Giles GG, et al. Higher dietary calcium intakes are associated with reduced risks of fractures, cardiovascular events, and mortality: a prospective cohort study of older men and women. J Bone Miner Res. (2015) 30:1758-66. doi: 10.1002/jbmr.2515

131. Lewis JR, Radavelli-Bagatini S, Rejnmark L, Chen JS, Simpson JM, Lappe JM, et al. The effects of calcium supplementation on verified coronary heart disease hospitalization and death in postmenopausal women: a collaborative meta-analysis of randomized controlled trials. J Bone Miner Res. (2015) 30:165-75. doi: 10.1002/jbmr.2311

132. Chiodini I, Bolland MJ. Calcium supplementation in osteoporosis: useful or harmful? Eur Soc Endocri. (2018) 178:D13-25. doi: 10.1530/EJE-18-0113

133. Bolland MJ, Barber PA, Doughty RN, Mason B, Horne A, Ames R, et al. Vascular events in healthy older women receiving calcium supplementation: randomised controlled trial. (2008) 336:262-6. doi: 10.1136/bmj.39440.525752.BE

134. Pentti K, Tuppurainen MT, Honkanen R, Sandini L, Kröger H, Alhava E, et al. Use of calcium supplements and the risk of coronary heart disease in 52-62-year-old women: The Kuopio Osteoporosis 
Risk Factor and Prevention Study. Maturitas (2009) 63:73-8. doi: $10.1016 /$ j.maturitas.2009.03.006

135. Bolland MJ, Grey A, Reid IR. Calcium supplements and cardiovascular risk: 5 years on. Ther Adv Drug Saf. (2013) 4:199-210. doi: $10.1177 / 2042098613499790$

136. Larsson SC. Are calcium supplements harmful to cardiovascular disease?. JAMA Intern Med. (2013) 173:647-8. doi: 10.1001/jamainternmed.2013.3769

137. Reid IR. Cardiovascular effects of calcium supplements. Nutrients (2013) 5:2522-29. doi: 10.3390/nu5072522

138. Xiao DQ, Murphy R. Dietary and supplemental calcium intakes in relation to mortality from cardiovascular diseases in the NIHAARP Diet and Health Study. JAMA Intern. (2013) 173:639-46. doi: 10.1001/jamainternmed.2013.3283

139. Tankeu AT, Ndip Agbor V, Noubiap JJ. Calcium supplementation and cardiovascular risk: a rising concern. J Clin Hypertens. (2017) 19:640-6. doi: 10.1111/jch.13010

140. Bristow SM, Gamble GD, Stewart A, Horne AM, Reid IR. Acute effects of calcium supplements on blood pressure and blood coagulation: secondary analysis of a randomised controlled trial in post-menopausal women. $\mathrm{Br} \mathrm{J}$ Nutr. (2015) 114:1868-74. doi: 10.1017/S0007114515003694

141. House MG, Kohlmeier L, Chattopadhyay N, Kifor O, Yamaguchi T, Leboff MS, et al. Expression of an extracellular calcium-sensing receptor in human and mouse bone marrow cells. J Bone Miner Res. (1997) 12:1959-70. doi: 10.1359/jbmr.1997.12.12.1959

142. Loeffen R, Spronk HMH, ten Cate H. The impact of blood coagulability on atherosclerosis and cardiovascular disease. J Thromb Haemost. (2012) 10:1207-16. doi: 10.1111/j.1538-7836.2012.04782.x

143. Chertow GM, Burke SK, Raggi P. Sevelamer attenuates the progression of coronary and aortic calcification in hemodialysis patients. Kidney Int. (2002) 62:245-52. doi: 10.1046/j.1523-1755.2002.00434.x

144. Ramirez JA, Emmett M, White MG, Fathi N, Santa Ana CA, Morawski SG, et al. The absorption of dietary phosphorus and calcium in hemodialysis patients. Kidney Int. (1986) 30:753-9. doi: 10.1038/ki.1986.252

145. Caravaca F, Caravaca-Fontán F, Azevedo L, Luna E. How to assess the efficacy of phosphate binders. Nefrologia 37:311-9. doi: 10.1016/j.nefro.2016.11.012

146. Lewis JR, Zhu K, Prince RL. Adverse events from calcium supplementation: Relationship to errors in myocardial infarction self-reporting in randomized controlled trials of calcium supplementation. J Bone Miner Res. (2012) 27:719-22. doi: $10.1002 / j b m r .1484$

147. Dam H, Schonheyder F. The occurrence and chemical nature of vitamin K. Biochem J. (1936) 30:897-901. doi: 10.1042/bj0300897

148. Shearer MJ, Newman P. Metabolism and cell biology of vitamin K. Thromb Haemost. (2008) 100:530-47. doi: 10.1160/TH08-03-0147

149. Taber HW, Dellers EA, Lombardo LR. Menaquinone biosynthesis in Bacillus subtilis: isolation of men mutants and evidence for clustering of men genes. J Bacteriol. (1981) 145:321-7.

150. Morishita T, Tamura N, Makino T, Kudo S. Production of menaquinones by lactic acid bacteria. J Dairy Sci. (1999) 82:1897-903. doi: 10.3168/jds.S0022-0302(99)75424-X

151. Bentley R, Meganathan R. Biosynthesis of vitamin K (menaquinone) in bacteria. Microbiol Rev. (1982) 46:241-80.

152. Nelsestuen GL. Interactions of vitamin K-dependent proteins with calcium ions and phospholipid membranes. Fed Proc. (1978) 37:2621-5.

153. Esmon CT, Sadowski JA, Suttie JW. A new carboxylation reaction. the vitamin K-dependent incorporation of H-14-CO3- into prothrombin. J Biol Chem. (1975) 250:4744-8.

154. Schurgers LJ, Vermeer C. Determination of phylloquinone and menaquinones in food. Effect of food matrix on circulating vitamin $\mathrm{K}$ concentrations. Haemostasis (2000) 30:298-307. doi: 10.1159/000054147

155. Schurgers LJ, Vermeer C. Differential lipoprotein transport pathways of K-vitamins in healthy subjects. Biochim Biophys Acta - Gen Subj. (2002) 1570:27-32. doi: 10.1016/S0304-4165(02)00147-2

156. Viegas CS, Herfs M, Rafael MS, Enriquez JL, Teixeira A, Luís IM, et al. Gla-rich protein is a potential new vitamin $\mathrm{K}$ target in cancer: Evidences for a direct GRP-mineral interaction. Biomed Res Int. (2014) 2014. doi: $10.1155 / 2014 / 340216$

157. Schinke T, Karsenty G, Schinke T. Vascular calcification-a passive process in need of inhibitors. Nephrol Dial Transplant. (2000) 15:1272-4. doi: $10.1093 /$ ndt/15.9.1272
158. Kapustin AN, Schoppet M, Schurgers LJ, Reynolds JL, McNair R, Heiss A, et al. Prothrombin Loading of Vascular Smooth Muscle Cell-Derived Exosomes Regulates Coagulation and Calcification. Arterioscler Thromb Vasc Biol. (2017) 37:e22-32. doi: 10.1161/ATVBAHA.116.308886

159. Young MF. Bone matrix proteins: their function, regulation, and relationship to osteoporosis. Osteoporos Int. (2003) 14:35-42. doi: 10.1007/s00198-002-1342-7

160. Gorski JP. Biomineralization of bone: a fresh view of the roles of noncollagenous proteins. Front Biosci. (Landmark Ed)(2011) 16:2598-621. doi: $10.2741 / 3875$

161. Ducy P, Desbois C, Boyce B, Pinero G, Story B, Dunstan C, et al. Increased bone formation in osteocalcin-deficient mice. Nature (1996) 382:448-52. doi: $10.1038 / 382448 \mathrm{a} 0$

162. Gundberg CM, Lian JB, Booth SL. Vitamin K-dependent carboxylation of osteocalcin: friend or foe?. Adv Nutr. (2012) 3:149-57. doi: 10.3945/an.112.001834

163. Lambert LJ, Challa AK, Niu A, Zhou L, Tucholski J, Johnson MS, et al. Increased trabecular bone and improved biomechanics in an osteocalcinnull rat model created by CRISPR/Cas9 technology. Dis ModelMech. (2016) 9:1169-79. doi: 10.1242/dmm.025247

164. Karsenty G, Oury F. Regulation of male fertility by the bonederived hormone osteocalcin. Mol Cell Endocrinol. (2014) 382:521-6. doi: 10.1016/j.mce.2013.10.008

165. Lee NK, Sowa H, Hinoi E, Ferron M, Ahn JD, Confavreux C, et al. Endocrine regulation of energy metabolism by the skeleton. (2007) 130:45669. doi: 10.1016/j.cell.2007.05.047

166. Ferron M, Lacombe J. Regulation of energy metabolism by the skeleton: Osteocalcin and beyond. Arch Biochem Biophys. (2014) 561:137-46. doi: 10.1016/j.abb.2014.05.022

167. Shiraki M. [Health benefits and demerits of calcium nutrition or supplementation in older people]. Nihon Rinsho. (2015) 73:1770-6.

168. Zoch ML, Clemens TL, Riddle RC. New insights into the biology of osteocalcin. Bone (2016) 82:42-9. doi: 10.1016/j.bone.2015.05.046

169. Kalaiselvi VS, Prabhu K, Ramesh M, Venkatesan V. The association of serum osteocalcin with the bone mineral density in post menopausal women. J Clin Diagnostic Res. (2013) 7:814-6. doi: 10.7860/JCDR/2013/5370.2946

170. Susanto LTM. Serum osteocalcin and bone mineral density in postmenopausal women. Universa Med. (2011) 30:155-61. doi: 10.18051/UnivMed.2011.v30.155-161

171. Hendrijantini N, Alie R, Setiawati R, Astuti ER, Wardhana MP. The correlation of bone mineral density (BMD), body mass index (BMI) and osteocalcin in postmenopausal women. (2016) 8:6-10. doi: 10.4172/0974-8369.1000319

172. Kalkwarf HJ, Khoury JC, Bean J, Elliot JG. Vitamin K, bone turnover, and bone mass in girls. Am J Clin Nutr. (2004) 80:1075-80. doi: $10.1093 /$ ajcn/80.4.1075

173. Price PA, Urist MR, Otawara Y. Matrix Gla protein, a new gammacarboxyglutamic acid-containing protein which is associated with the organic matrix of bone. Biochem Biophys Res Commun. (1983) 117:765-71. doi: 10.1016/0006-291X(83)91663-7

174. Shanahan CM, Cary NR, Metcalfe JC, Weissberg PL. High expression of genes for calcification-regulating proteins in human atherosclerotic plaques. J Clin Invest. (1994) 93:2393-402. doi: 10.1172/JCI117246

175. Dhore CR, Cleutjens JP, Lutgens E, Cleutjens KB, Geusens PP, Kitslaar PJ, et al. Differential expression of bone matrix regulatory proteins in human atherosclerotic plaques. Arter Thromb Vasc Biol. (2001) 21:19982003. doi: $10.1161 / \mathrm{hq} 1201.100229$

176. Fraser JD, Price PA. Lung, heart, and kidney express high levels of mRNA for the vitamin K-dependent matrix Gla protein. Implications for the possible functions of matrix Gla protein and for the tissue distribution of the gammacarboxylase. J Biol Chem. (1988) 263:11033-6.

177. Luo G, Ducy P, McKee MD, Pinero GJ, Loyer E, Behringer RR, et al. Spontaneous calcification of arteries and cartilage in mice lacking matrix GLA protein. Nature (1997) 386:78. doi: 10.1038/386078a0

178. Munroe PB, Olgunturk RO, Fryns JP, Van Maldergem L, Ziereisen F, Yuksel $\mathrm{B}$, et al. Mutations in the gene encoding the human matrix Gla protein cause Keutel syndrome. Nat Genet. (1999) 21:142-4. doi: 10.1038/5102

179. Schurgers LJ, Joosen IA, Laufer EM, Chatrou ML, Herfs M, Winkens $\mathrm{MH}$, et al. Vitamin K-antagonists accelerate atherosclerotic calcification 
and induce a vulnerable plaque phenotype. PLOS ONE (2012) 7:8. doi: 10.1371/journal.pone.0043229

180. Schurgers LJ, Teunissen KJ, Knapen MH, Kwaijtaal M, van Diest R, Appels A, et al. Novel conformation-specific antibodies against matrix $\gamma$ carboxyglutamic acid (Gla) protein: undercarboitylated matrix Gla protein as marker for vascular calcification. Arterioscler Thromb Vasc Biol. (2005) 25:1629-33. doi: 10.1161/01.ATV.0000173313.46222.43

181. Murshed M, Schinke T, McKee MD, Karsenty G. Extracellular matrix mineralization is regulated locally; different roles of two gla-containing proteins. J Cell Biol. (2004) 165:625-30. doi: 10.1083/jcb.200402046

182. Gröber U, Reichrath J, Holick MF, Kisters K. Vitamin K: an old vitamin in a new perspective. Dermatoendocrinology (2015) 6:e968490. doi: 10.4161/19381972.2014.968490

183. Yao Y, Zebboudj AF, Shao E, Perez M, Bostrom K. Regulation of bone morphogenetic protein- 4 by matrix GLA protein in vascular endothelial cells involves activin-like kinase receptor 1. J Biol Chem. (2006) 281:33921-30. doi: 10.1074/jbc.M604239200

184. Zebboudj AF, Imura M, Bostrom K. Matrix GLA protein, a regulatory protein for bone morphogenetic protein-2. J Biol Chem. (2002) 277:4388-94. doi: 10.1074/jbc.M109683200

185. Boström K, Watson KE, Horn S, Wortham C, Herman IM, Demer LL. Bone morphogenetic protein expression in human atherosclerotic lesions. J Clin Invest. (1993) 91:1800-9. doi: 10.1172/JCI116391

186. Li X, H.-Yang Y, Giachelli CM. BMP-2 Promotes phosphate uptake, phenotypic modulation, and calcification of human vascular smooth muscle cells. Atherosclerosis (2008) 199:271-7. doi: 10.1016/j.atherosclerosis.2007.11.031

187. Zebboudj AF, Shin V, Boström K. Matrix GLA Protein and BMP-2 regulate osteoinduction in calcifying vascular cells. J Cell Biochem. (2003) 90:756-65. doi: $10.1002 /$ jcb.10669

188. Speer MY, McKee MD, Guldberg RE, Liaw L, Yang HY, Tung E, et al. Inactivation of the osteopontin gene enhances vascular calcification of matrix gla protein-deficient mice. J Exp Med. (2002) 196:1047-55. doi: 10.1084/jem.20020911

189. Tagariello A, Luther J, Streiter M, Didt-Koziel L, Wuelling M, SurmannSchmitt C, et al. Ucma-A novel secreted factor represents a highly specific marker for distal chondrocytes. Matrix Biol. (2008) 27:3-11. doi: 10.1016/j.matbio.2007.07.004

190. Surmann-Schmitt C, Dietz U, Kireva T, Adam N, Park J, Tagariello A, et al. Ucma, a novel secreted cartilage-specific protein with implications in osteogenesis. J Biol Chem. (2008) 283:7082-93. doi: 10.1074/jbc.M702792200

191. Viegas CS, Simes DC, Laizé V. Williamson MK, Price PA, Cancela ML. Glarich protein (GRP), a new vitamin K-dependent protein identified from sturgeon cartilage and highly conserved in vertebrates. J Biol Chem. (2008) 283:36655-64. doi: 10.1074/jbc.M802761200

192. Viegas CS, Cavaco S, Neves PL, Ferreira A, João A, Williamson MK, et al. Gla-rich protein is a novel vitamin K-dependent protein present in serum that accumulates at sites of pathological calcifications. Am J Pathol. (2009) 175:2288-98. doi: 10.2353/ajpath.2009.090474

193. Viegas CS, Rafael MS, Enriquez JL, Teixeira A, Vitorino R, Luís IM, et al. Gla-rich protein acts as a calcification inhibitor in the human cardiovascular system. Arterioscler Thromb Vasc Biol. (2015) 35:399-408. doi: 10.1161/ATVBAHA.114.304823

194. Eitzinger N, Surmann-Schmitt C, Bösl M, Schett G, Engelke K, Hess A, et al. $\mathrm{Ucma}$ is not necessary for normal development of the mouse skeleton. Bone (2012) 50:670-80. doi: 10.1016/j.bone.2011.11.017

195. Viegas CSB, Santos L, Macedo AL, Matos AA, Silva AP, Neves PL, et al. Chronic kidney disease circulating calciprotein particles and extracellular vesicles promote vascular calcification. Arterioscler Thromb Vasc Biol. (2018). 38:575-87. doi: 10.1161/ATVBAHA.117.310578

196. Lee YJ, Park SY, Lee SJ, Boo YC, Choi JY, Kim JE. Ucma, a direct transcriptional target of Runx2 and Osterix, promotes osteoblast differentiation and nodule formation. Osteoarthr Cartil. (2015) 23:1421-31. doi: 10.1016/j.joca.2015.03.035

197. Schurgers LJ, Uitto J, Reutelingsperger CP. Vitamin K-dependent carboxylation of matrix Gla-protein: a crucial switch to control ectopic mineralization. Trends Mol Med. (2013) 19:217-26. doi: 10.1016/j.molmed.2012.12.008
198. Price PA, Poser JW, Raman N. Primary structure of the gammacarboxyglutamic acid-containing protein from bovine bone. Proc Natl Acad Sci USA. (1976) 73:3374-5. doi: 10.1073/pnas.73.10.3374

199. Hauschka PV, Lian JB, Gallop PM. Direct identification of the calciumbinding amino acid, y-carboxyglutamate, in mineralized tissue. October, (1975) 72:3925-9.

200. Yagami K, Suh JY, Enomoto-Iwamoto M, Koyama E, Abrams WR, Shapiro IM, et al. Matrix GLA protein is a developmental regulator of chondrocyte mineralization and, when constitutively expressed, blocks endochondral and intramembranous ossification in the limb. J Cell Biol. (1999) 147:1097-108. doi: $10.1083 /$ jcb.147.5.1097

201. Hale JE, Fraser JD, Price PA. The identification of matrix Gla protein in cartilage. J Biol Chem. (1988) 263:5820-4.

202. Di Iorio B, Molony D, Bell C, Cucciniello E, Bellizzi V, Russo D, et al. Sevelamer versus calcium carbonate in incident hemodialysis patients: Results of an open-label 24-month randomized clinical trial. Am J Kidney Dis. (2013) 62:771-8. doi: 10.1053/j.ajkd.2013.03.023

203. Block GA, Spiegel DM, Ehrlich J, Mehta R, Lindbergh J, Dreisbach A, et al. Effects of sevelamer and calcium on coronary artery calcification in patients new to hemodialysis. Kidney Int. (2005) 68:1815-24. doi: 10.1111/j.1523-1755.2005.00600.x

204. Suki WN, Zabaneh R, Cangiano JL, Reed J, Fischer D, Garrett $\mathrm{L}$, et al. Effects of sevelamer and calcium-based phosphate binders on mortality in hemodialysis patients. Kidney Int. (2007) 72:1130-37. doi: 10.1038/sj.ki.5002466

205. Katai K, Tanaka H, Tatsumi S, Fukunaga Y, Genjida K, Morita K, et al. Nicotinamide inhibits sodium-dependent phosphate cotransport activity in rat small intestine. Nephrol Dial Transplant. (1999) 14:1195-201. doi: $10.1093 / \mathrm{ndt} / 14.5 .1195$

206. Chan S. Phosphate binders in patients with chronic kidney disease. Aust Prescr. (2017) 4040:9-14. doi: 10.18773/austprescr.2017.002

207. El Borolossy R, El Wakeel LM, El Hakim I, Sabri N. Efficacy and safety of nicotinamide in the management of hyperphosphatemia in pediatric patients on regular hemodialysis. Pediatr Nephrol. (2016) 31:289-96. doi: 10.1007/s00467-015-3208-1

208. Ito K, Takeshima A, Shishido K, Wakasa M, Kumata C, Matsuzaka K, et al. Treatment of hyperphosphatemia with bixalomer in Japanese patients on long-term hemodialysis with gastrointestinal symptoms. Ther Apher Dial. (2014) 18(Suppl 2):19-23. doi: 10.1111/1744-9987.12229

209. Navaneethan SD, Palmer SC, Vecchio M, Craig JC, Elder GJ, Strippoli GF. Phosphate binders for preventing and treating bone disease in chronic kidney disease patients. Cochrane Database Syst Rev. (2011) CD006023. doi: 10.1002/14651858.CD006023.pub2

210. Locatelli F, Spasovski G, Dimkovic N, Wanner C. Long-Term Evaluation of Colestilan in Chronic Kidney Disease Stage 5 Dialysis Patients with Hyperphosphataemia. Blood Purif. (2016) 41:247-53. doi: $10.1159 / 000441648$

211. Locatelli F, Del Vecchio L, Violo L, Pontoriero G. Phosphate binders for the treatment of hyperphosphatemia in chronic kidney disease patients on dialysis: a comparison of safety profiles. Expert Opin Drug Saf. (2014) 13:551-61. doi: 10.1517/14740338.2014.907791

212. Van Buren PN, Lewis JB, Dwyer JP, Greene T, Middleton J, Sika M, et al. The phosphate binder ferric citrate and mineral metabolism and inflammatory markers in maintenance dialysis patients: results from prespecified analyses of a randomized clinical Trial. Am J Kidney Dis. (2015) 66:479-88. doi: 10.1053/j.ajkd.2015.03.013

213. Yokoyama K, Hirakata H, Akiba T, Fukagawa M, Nakayama M, Sawada $\mathrm{K}$, et al. Ferric citrate hydrate for the treatment of hyperphosphatemia in nondialysis-dependent CKD. Clin J Am Soc Nephrol. (2014) 9:543-52. doi: 10.2215/CJN.05170513

214. de Francisco AL, Belmar L, Piñera C, Kislikova M, Seras M, Serrano $M$, et al. Effect of calcium acetate/magnesium carbonate in the treatment of hyperphosphataemia in dialysis patients in real clinical practice. One year follow up. Nefrologia (2014) 34:617-27. doi: 10.3265/Nefrologia.pre2014.Jul.12527

215. Kakuta T, Tanaka R, Hyodo T, Suzuki H, Kanai G, Nagaoka M, et al. Effect of sevelamer and calcium-based phosphate binders on coronary artery calcification and accumulation of circulating advanced glycation end 
products in hemodialysis patients. Am J Kidney Dis. (2011) 57:422-31. doi: 10.1053/j.ajkd.2010.10.055

216. Chue CD, Townend JN, Moody WE, Zehnder D, Wall NA, Harper L, et al. Cardiovascular Effects of Sevelamer in Stage 3 CKD. J Am Soc Nephrol. (2013) 24:842-52. doi: 10.1681/ASN.2012070719

217. Chertow GM, Burke SK, Dillon MA, Slatopolsky E. Long-term effects of sevelamer hydrochloride on the calcium $\mathrm{x}$ phosphate product and lipid profile of haemodialysis patients. Nephrol Dial Transplant. (1999) 14:290714. doi: $10.1093 / \mathrm{ndt} / 14.12 .2907$

218. Neradova A, Schumacher SP, Hubeek I, Lux P, Schurgers LJ, Vervloet MG. Phosphate binders affect vitamin K concentration by undesired binding, an in vitro study. BMC Nephrol. (2017) 18:149. doi: 10.1186/s12882-017-0560-3

219. Takagi K, Masuda K, Yamazaki M, Kiyohara C, Itoh S, Wasaki M, et al. Metal ion and vitamin adsorption profiles of phosphate binder ion-exchange resins. Clin Nephrol. (2010) 73:30-5. doi: 10.5414/CNP73030

220. Neradova A, Schumacher S, Lux P, Schurgers L, Vervloet M. Mp377Phosphate binders, vitamin K absorption. Nephrol Dial Transplant. (2016) 31(Suppl_1):i465. doi: 10.1093/ndt/gfw190.34

221. Jansz TT, Neradova A, van Ballegooijen AJ, Verhaar MC, Vervloet MG, Schurgers LJ, et al. The role of kidney transplantation and phosphate binder use in vitamin K status. PLoS ONE (2018) 13:1-13. doi: 10.1371/journal.pone.0203157

222. Cernaro V, Santoro D, Lacquaniti A, Costantino G, Visconti L, Buemi A, et al. Phosphate binders for the treatment of chronic kidney disease: role of iron oxyhydroxide. Int J Nephrol Renovasc Dis. (2016) 9:11-9. doi: 10.2147/IJNRD.S78040

223. Pilkey RM, Morton AR, Boffa MB, Noordhof C, Day AG, Su Y, et al. Subclinical vitamin K deficiency in hemodialysis patients. Am J Kidney Dis. (2007) 49:432-9. doi: 10.1053/j.ajkd.2006.11.041

224. Schurgers LJ, Barreto DV, Barreto FC, Liabeuf S, Renard C, Magdeleyns EJ, et al. The circulating inactive form of matrix gla protein is a surrogate marker for vascular calcification in chronic kidney disease: a preliminary report. Clin J Am Soc Nephrol. (2010) 5:568-75. doi: 10.2215/CJN.07081009

225. Akedo Y, Hosoi T, Inoue S, Ikegami A, Mizuno Y, Kaneki M, et al. Vitamin k2 modulates proliferation and function of osteoblastic cells in vitro. (1992) 187:814-20.

226. Akiyama Y, Hara K, Tajima T, Murota S, Morita I. Effect of vitamin K2 (menatetrenone) on osteoclast-like cell formation in mouse bone marrow cultures. Eur J Pharmacol. (1994) 263:181-5. doi: 10.1016/0014-2999(94)90539-8

227. Koshihara Y, Hoshi K, Shiraki M. Vitamin K2 (menatetrenone) inhibits prostaglandin synthesis in cultured human osteoblast-like periosteal cells by inhibiting prostaglandin $\mathrm{H}$ synthase activity. Biochem Pharmacol. (1993) 46:1355-62. doi: 10.1016/0006-2952(93)90099-I

228. Yamaguchi $M$, Taguchi H, Gao YH, Igarashi A, Tsukamoto Y. Effect of vitamin K2 (menaquinone-7) in fermented soybean (natto) on bone loss in ovariectomized rats. J Bone Miner Metab. (1999) 17:23-9. doi: 10.1007/s007740050059

229. Ishida Y, Kawai S. Comparative efficacy of hormone replacement therapy, etidronate, calcitonin, alfacalcidol, and vitamin K in postmenopausal women with osteoporosis: the yamaguchi osteoporosis prevention study. Am J Med. (2018) 117:549-55. doi: 10.1016/j.amjmed.2004.05.019

230. Knapen MH, Drummen NE, Smit E, Vermeer C, Theuwissen E.Article O. Three-year low-dose menaquinone-7 supplementation helps decrease bone loss in healthy postmenopausal women. Osteoporos Int. (2013) 24:2499-507. doi: 10.1007/s00198-013-2325-6

231. Caluwé, R. Vandecasteele S, Van Vlem B, Vermeer C, De Vriese AS. Vitamin K2 supplementation in haemodialysis patients: a randomized dose-finding study. Nephrol Dial Transplant. (2014) 29:1385-90. doi: 10.1093/ndt/gft464

232. Shiraki M, Shiraki Y, Aoki C, Miura M. Vitamin K2 (menatetrenone) effectively prevents fractures and sustains lumbar bone mineral density in osteoporosis. J Bone Miner Res. (2000) 15:515-21. doi: 10.1359/jbmr.2000.15.3.515

233. Binkley N, Harke J, Krueger D, Engelke J, Vallarta-Ast N, Gemar $\mathrm{D}$, et al. Vitamin $\mathrm{K}$ treatment reduces undercarboxylated osteocalcin but does not alter bone turnover, density, or geometry in healthy postmenopausal North American women. J Bone Miner Res. (2009) 24:98391. doi: $10.1359 /$ jbmr. 081254

234. Koitaya N, Sekiguchi M, Tousen Y, Nishide Y, Morita A, Yamauchi J, et al. Low-dose vitamin K2 (MK-4) supplementation for 12 months improves bone metabolism and prevents forearm bone loss in postmenopausal Japanese women. J Bone Miner Metab. (2014) 32:142-50. doi: 10.1007/s00774-013-0472-7

235. Koitaya N, Ezaki J, Nishimuta M, Yamauchi J, Hashizume E, Morishita K, et al. Effect of low dose vitamin K2 (MK-4) supplementation on bio- indices in postmenopausal japanese women. J Nutr Sci Vitaminol. (2009) 55:15-21. doi: $10.3177 /$ jnsv. 55.15

236. Iwamoto J. Vitamin $\mathrm{K} 2$ therapy for postmenopausal osteoporosis. Nutrients (2014) 6:1971-80. doi: 10.3390/nu6051971

237. Shiraki M, Itabashi A. Short-term menatetrenone therapy increases gammacarboxylation of osteocalcin with a moderate increase of bone turnover in postmenopausal osteoporosis: a randomized prospective study. J Bone Miner Metab. (2009) 27:333-40. doi: 10.1007/s00774-008-0034-6

238. Hirao M, Hashimoto J, Ando W, Ono T, Yoshikawa H. Response of serum carboxylated and undercarboxylated osteocalcin to alendronate monotherapy and combined therapy with vitamin K2 in postmenopausal women. J Bone Miner Metab. (2008) 26:260. doi: 10.1007/s00774-007-0823-3

239. Braam LA, Hoeks AP, Brouns F, Halmuyák K, Gerichhausen MJ, Vermeer C. Beneficial effects of vitamins $\mathrm{D}$ and $\mathrm{K}$ on the elastic properties of the vessel wall in postmenopausal women: a follow-up study. Thromb Haemost. (2004) 91:373-80. doi: 10.1160/TH03-07-0423

240. Geleijnse JM, Vermeer C, Grobbee DE, Schurgers LJ, Knapen MH, van der Meer IM, et al. Dietary intake of menaquinone is associated with a reduced risk of coronary heart disease: the rotterdam study. J Nutr. (2004) 134:3100-5. doi: 10.1093/jn/134.11.3100

241. Vossen LM, Schurgers LJ, van Varik BJ, Kietselaer BL, Vermeer C, Meeder JG, et al. Menaquinone-7 supplementation to reduce vascular calcification in patients with coronary artery disease: rationale and study protocol (VitaKCAC Trial). Nutrients (2015) 7:8905-15. doi: 10.3390/nu7115443

242. Beulens JW, Bots ML, Atsma F, Bartelink ML, Prokop M, Geleijnse $\mathrm{JM}$, et al. High dietary menaquinone intake is associated with reduced coronary calcification. Atherosclerosis (2008) 203:489-93. doi: 10.1016/j.atherosclerosis.2008.07.010

243. Thamratnopkoon S, Susantitaphong P, Tumkosit M, Katavetin P, Tiranathanagul K, Praditpornsilpa K, et al. Clinical Practice : original paper correlations of plasma desphosphorylated uncarboxylated matrix gla protein with vascular calcification and vascular stiffness in chronic Kidney Disease. Nephron. (2017) 135:167-72. doi: 10.1159/000453368

244. Schlieper G, Westenfeld R, Krüger T, Cranenburg EC, Magdeleyns EJ, Brandenburg VM, et al. Circulating nonphosphorylated carboxylated matrix gla protein predicts survival in ESRD. J Am Soc.Nephrol. (2011) 22:387-95. doi: 10.1681/ASN.2010040339

Conflict of Interest Statement: Nattopharma ASA received an industrial Ph.D. grant from the Norwegian Research Council to conduct research in collaboration with the Maastricht University. GW has been employed as Ph.D. student to work on this project. Nattopharma ASA is a pharmaceutical company with interest in vitamin $\mathrm{K} 2$.

The remaining authors declare that the research was conducted in the absence of any commercial or financial relationships that could be construed as a potential conflict of interest.

Copyright $\odot 2019$ Wasilewski, Vervloet and Schurgers. This is an open-access article distributed under the terms of the Creative Commons Attribution License (CC BY). The use, distribution or reproduction in other forums is permitted, provided the original author(s) and the copyright owner(s) are credited and that the original publication in this journal is cited, in accordance with accepted academic practice. No use, distribution or reproduction is permitted which does not comply with these terms. 